\title{
Resinas termofixas e a produção de refratários contendo carbono: base teórica e insights para futuros desenvolvimentos
}

\section{(Thermosetting resins and the production of carbon containing refractories: theoretic basis and insights for future developments)}

\author{
C. S. Bitencourt, V. C. Pandolfelli \\ Departamento de Engenharia de Materiais, Universidade Federal de S. Carlos, Rod. Washington Luiz, km 235, \\ C. P. 676, S. Carlos, SP 13565-905 \\ celina_ufscar@yahoo.com.br,vicpando@power.ufscar.br
}

\begin{abstract}
Resumo
Por suas diversas vantagens em relação ao piche de alcatrão convencional, o uso das resinas termofixas fenólicas vem se expandindo na produção dos refratários contendo carbono. Contudo, apesar desta tendência, ainda se verificam poucos trabalhos publicados no meio acadêmico que se proponham a investigar como alterações nas características desses polímeros podem afetar e beneficiar o processamento e as propriedades dos refratários. Algumas pesquisas reportam os efeitos dessas alterações sobre a pirólise do termofixo isolado. Entretanto, empregar plenamente as suas conclusões nos estudos em refratários pode não ser adequado, visto que os demais componentes e os próprios métodos de processamento desses materiais podem ter uma importante influência sobre o comportamento do termofixo. Assim, procurando verificar os caminhos mais promissores para desenvolver resinas fenólicas que apresentem um desempenho otimizado para essa aplicação específica, este artigo faz uma revisão geral sobre a química desses termofixos e suas conseqüências para o processamento do refratário e para a geração de carbono. Também serão revisados alguns aditivos capazes de auxiliar a resina a alcançar tal desempenho superior, entre eles os chamados agentes grafitizantes, que teriam a função de induzir a cristalização do carbono produzido pelo termofixo, um fenômeno antes exclusivo de fontes de carbono grafitizáveis como os piches.
\end{abstract}

Palavras-chave: resinas termofixas, refratários contendo carbono, grafitização.

\begin{abstract}
Based on the many advantages over the conventional coal tar pitch, the application of thermosetting phenolic resins has been expanding for the production of carbon containing refractories. Nevertheless, despite this trend, it is noticeable that there are few published technical and scientific papers aiming to investigate how modifications in these polymers characteristics could affect and benefit the refractories processing and properties. There are studies in the literature analyzing the effects of these modifications on the pyrolysis of the thermoset itself. However, to fully apply their conclusions in the refractories research may not be appropriate, because the other components and even the processing methods of these materials may have an important influence on the behavior of the thermoset. Thus, with the objective to analyze the most promising ways to develop phenolic resins with an improved performance for this specific application, this work reviews the chemistry of thermosets and its consequences for the refractory processing and carbon production. The effect of some additives which could help the resins attaining such performance are also revised, including these so-called graphitizing agents, which induce crystallization in the thermoset derived carbon, a benefit before exclusive of graphitizable carbon sources as pitches.
\end{abstract}

Keywords: thermosetting resins, carbon containing refractories, graphitization.

\section{INTRODUÇÃO}

A aplicação do grafite na produção de refratários para a siderurgia vem evoluindo e se expandindo desde meados do século 18, e até hoje as propriedades desse alótropo do carbono são alvo de grande atenção pela importância dos benefícios que proporcionam ao desempenho dos refratários. Entre esses benefícios, é possível destacar o aumento da resistência ao dano por choque térmico, uma conseqüência do baixo coeficiente de expansão térmica e da boa condutividade térmica do grafite, e os ganhos na resistência à corrosão e à erosão provocadas pelas escórias siderúrgicas, os quais resultam da baixa molhabilidade do grafite pelos óxidos fundidos que compõem as escórias. Todas essas qualidades implicam em uma vida útil prolongada aos revestimentos de alto-fornos, panelas (na linha de escória), convertedores e de outros equipamentos da cadeia do aço, reduzindo dessa maneira o consumo dos insumos de produção, os custos com os serviços de manutenção e a freqüência de interrupções do processo produtivo. A própria qualidade do metal também acaba sendo favorecida, uma vez que o desgaste mais lento do refratário diminui o problema das inclusões não-metálicas. Essas e outras vantagens da classe dos refratários contendo carbono têm sido significativamente ampliadas nas últimas 
décadas devido à evolução desses materiais. Inclusive, em conjunto com outros fatores como o estabelecimento de novas tecnologias de produção e com os avanços nas práticas operacionais, essa evolução tem sido uma das responsáveis pela contínua queda do consumo de refratários por tonelada de aço produzida, um valor que em 1970 era $\sim 30 \mathrm{~kg} /$ ton e que, atualmente, já pode ser encontrado abaixo de $10 \mathrm{~kg} / \mathrm{ton}$ [1-3]. Por também significar a redução na geração de resíduos, tal conquista ganha ainda mais valor neste momento em que se intensifica a pressão sobre o meio industrial para que este invista na sustentabilidade de seus processos e produtos. Porém, não se deve se limitar a observar essas vantagens apenas do ponto de vista do setor siderúrgico. Para a própria indústria de refratários, dispor de produtos que consigam atingir tal desempenho não significa apenas agregar-lhes valor, como também permite que a exploração dos recursos naturais finitos que fornecem suas matérias-primas seja feita de forma mais efetiva e por um período de tempo mais extenso, um aspecto especialmente crítico para as reservas minerais. Contudo, apesar de tantas vantagens, quando são observadas as questões da emissão de poluentes e da insalubridade do ambiente de trabalho os refratários contendo carbono podem passar de solução a problema. Isso porque justamente uma das fontes de carbono mais usadas em suas composições, o piche de alcatrão, tem por característica liberar uma grande quantidade de substâncias tóxicas e cancerígenas durante sua pirólise, com destaque para alguns hidrocarbonetos aromáticos policíclicos, como o benzopireno [4-7]. Apesar disso, o piche de alcatrão continua a ser aplicado pela indústria refratária, principalmente por seu baixo custo e por se tratar de uma fonte de carbono grafitizável $[2,7,8]$. Embora as temperaturas em que trabalham os refratários da siderurgia não permitam que o processo de grafitização seja completo, essa capacidade já garante que o carbono produzido pelo piche apresentará propriedades mais próximas às do grafite (ou seja, alta condutividade térmica, baixa molhabilidade pelas escórias siderúrgicas, baixo coeficiente de expansão térmica, entre outras). Já no caso de fontes de carbono que não possuem a capacidade de grafitização, além de possuir propriedades físicas e mecânicas inferiores, o carbono formado por elas também acaba sendo mais susceptível à oxidação por apresentar uma maior área superficial e maior número de sítios reativos $[2,9,10]$. Conseqüentemente, o refratário produzido com fontes de carbono não grafitizáveis será mais sensível às suas condições de trabalho e poderá sofrer uma deterioração mais rápida com o tempo de serviço. Em vista do seu ponto de amolecimento geralmente baixo (entre $80 \mathrm{e}$ $120^{\circ} \mathrm{C}$, de acordo com sua composição [8]), o piche também apresenta as vantagens de proporcionar fluidez à composição do refratário quando o processo de mistura desta é realizado a quente, e de agir em seguida como um ligante, após a peça refratária ter sido moldada e resfriada. Isso então acaba por tornar o uso da água e de agentes cimentantes desnecessário, o que é especialmente benéfico quando da presença de óxidos susceptíveis à hidratação, como o $\mathrm{MgO}$ e o $\mathrm{CaO}$.

Quanto aos outros métodos usados pela indústria para enriquecer o refratário em carbono, o acréscimo de "flakes" de grafite é um procedimento comum e benéfico, visto a elevada cristalinidade deste material. No entanto, os teores passíveis de adição são limitados devido à baixa molhabilidade do grafite pela maioria dos líquidos, e também pela própria geometria lamelar dessas partículas, fatores que favorecem sua segregação nas etapas de mistura e moldagem da composição refratária [11]. Quanto ao negro de fumo, a adição desse material não seria muito vantajosa em uma primeira análise, pois ele tanto não pode contribuir com a fluidez ou atuar como um ligante para a composição, como também não é classificado como uma fonte de carbono grafitizável [12]. Assim, verifica-se a dificuldade para descartar o uso do piche pela importância das funções que ele exerce nos refratários contendo carbono. Porém, substituí-lo é uma necessidade inevitável em vista das restrições às quais sua aplicação já está sendo submetida em diversos países, justamente por sua toxicidade e pelos problemas ambientais que sua produção e uso acarretam [13]. Mesmo o desenvolvimento recente de piches de baixa emissão de compostos aromáticos não deverá ser suficiente para permitir que essa matéria-prima retome o seu mercado. Além de mais caros em relação ao piche comum, esses produtos também apresentam pontos de amolecimento mais elevados, que acabam por inviabilizar o processo de mistura a quente. No caso de serem liquefeitos com o uso de solventes, o que então permitiria a mistura a frio, a capacidade de fixação de carbono desses piches beneficiados acaba por ser muito reduzida. Em meio a tal situação, os únicos materiais que tem se mostrado capazes de substituir satisfatoriamente o piche na indústria de refratários são as resinas termofixas. De fato, a aplicação dessas resinas na produção de refratários já ocorre há mais de 30 anos, mas, nos últimos tempos, o seu uso cresceu de tal forma que, nos dias atuais, elas já estariam dominando alguns mercados. As resinas termofixas inclusive já seriam os ligantes orgânicos mais aplicados na produção de tijolos de MgO-C [6, 7]. Tal como o piche, as resinas também podem proporcionar fluidez e atuar como ligantes e fontes de carbono para o refratário (embora esse carbono seja do tipo não grafitizável). Contudo, deve-se ressaltar que as resinas termofixas têm conquistado o seu espaço não apenas por suas semelhanças para com o piche, mas principalmente pelas suas diversas vantagens em relação a ele, como: Suas emissões de hidrocarbonetos aromáticos policíclicos e de outras substâncias tóxicas durante a pirólise são mínimas [11, 14]; proporcionam maior salubridade ao ambiente de trabalho [15]; Após sua cura, a resina confere uma alta resistência mecânica ao refratário a verde [8]; as resinas podem colaborar para a redução da porosidade do refratário [11]; ao contrário do piche, as resinas curadas não adquirirem plasticidade durante o seu aquecimento até a temperatura de pirólise $[4,8,16]$, permitindo que a peça refratária mantenha a sua geometria, mesmo que essa seja complexa; o consumo de energia para o processamento do refratário é reduzido quando do uso de resinas que permitem que o processo de mistura seja realizado a frio $[4,16]$; as resinas possibilitam um maior teor de sólidos na composição do refratário, inclusive de partículas de grafite e negro de fumo [16]; sua pirólise pode levar à fixação de maiores porcentagens de carbono [17]; a 
grande variedade de formas e de propriedades possíveis às resinas permite a escolha do tipo mais adequado para cada aplicação $[2,11,13]$; e por serem sintéticas, as propriedades das resinas são mais previsíveis que as do piche. Assim, ainda que se desconsiderem os benefícios quanto à salubridade $\mathrm{e}$ às emissões tóxicas, verifica-se que as demais vantagens oferecidas pelas resinas termofixas favorecem não somente a indústria de refratários como também as próprias siderúrgicas, tornando a aplicação desses materiais um interesse comum. Apesar disso, analisando as pesquisas desenvolvidas no campo dos refratários contendo carbono, percebe-se que o uso das resinas termofixas talvez ainda esteja sendo alvo de um tratamento muito preliminar. Um sinal disso é que praticamente não são encontrados trabalhos que analisem com profundidade como alterações na composição da resina podem acabar afetando as propriedades do refratário. Também são observadas poucas tentativas para relacionar a composição da resina com a estrutura e as propriedades do polímero curado e do carbono obtido após a pirólise. É evidente que a raridade desses estudos em muito se deve à própria complexidade da química dos termofixos, a qual ainda não é completamente compreendida. Ainda assim, acreditase que esses aprofundamentos são necessários para que se possa desenvolver resinas que levem o refratário a alcançar o seu máximo desempenho. Portanto, com o objetivo de identificar os caminhos a serem explorados para atingir tal propósito, este artigo pretende, primeiramente, revisar as bases da química das resinas termofixas e suas características e propriedades mais relevantes para a produção de refratários. Nisso, as resinas da classe das fenólicas serão o principal alvo de atenção, tanto por já serem as mais estudadas e aplicadas para a produção de refratários, como também por suas já atestadas vantagens quanto à versatilidade e à alta capacidade de fixar carbono, por seus custos relativamente baixos e por sua grande disponibilidade no mercado.

Sendo a incapacidade de grafitização do carbono derivado dos termofixos a principal desvantagem destes em relação ao piche, o capítulo 3 deste artigo abordará as teorias mais recentes sobre a estrutura do carbono não grafitizável, e sobre os motivos que acabam por impedi-lo de grafitizar mesmo quando submetido a temperaturas de mais de $3000{ }^{\circ} \mathrm{C}$. Já o capítulo 4 concentra-se na denominada grafitização catalítica, processo que, por meio do acréscimo de aditivos especiais às resinas, estaria se mostrando capaz de desenvolver a cristalização do carbono não grafitizável em condições viáveis tanto técnica quanto economicamente para a produção de refratários.

Nas conclusões desta revisão, serão apresentados os caminhos de pesquisa julgados como os mais promissores para desenvolver resinas termofixas voltadas para aplicações em refratários, isso levando em consideração, além dos benefícios às propriedades, os aspectos de processabilidade, praticidade e custos envolvidos em qualquer inovação.

\section{RESINAS TERMOFIXAS}

As resinas termofixas podem ser definidas como uma
Tabela I - Porcentagens de fixação de carbono usuais para o piche e polímeros diversos.

[Table I - Usual carbon yield attained by coal tar pitch and various polymers.]

\begin{tabular}{ccc}
\hline & \multicolumn{2}{c}{ Carbono fixo (\%p) } \\
\cline { 2 - 3 } Fonte de carbono & Ref. [13] & Ref. [17] \\
\hline Piche & - & $45-55$ \\
Resina fenólica & $55-70$ & $40-60$ \\
Resina furânicas & $55-60$ & $45-50$ \\
Resina epóxi & $25-35$ & - \\
Resina poliéster insaturada & $15-25$ & - \\
Poliacrilonitrila & - & $\approx 44$ \\
\hline
\end{tabular}

classe de substâncias orgânicas de baixo peso molecular que, sendo submetidas a condições propícias e/ou complementadas com aditivos específicos, passam por reações que dão origem a polímeros caracterizados por sua estrutura com alta densidade de ligações cruzadas. $\mathrm{O}$ conjunto dessas reações perfaz o chamado processo de cura. As ligações cruzadas são responsáveis pela alta rigidez e estabilidade desses materiais à ação de solventes e à elevação da temperatura, tornando-os insolúveis e infusíveis, comportamento que justamente lhes confere a denominação termofixo [18]. Assim, sem que passem por um estado plástico, o aquecimento acima de um determinado nível de temperatura leva diretamente ao início do processo de degradação desses polímeros. De acordo com suas características, como sua distribuição de pesos moleculares e com a estrutura de suas moléculas, as resinas termofixas puras podem ser encontradas à temperatura ambiente em estados físicos que variam de líquidos de baixa viscosidade a materiais sólidos. No caso de sólidas, as resinas ainda podem dissolvidas por alguns solventes específicos, assim como fundidas com o aquecimento. Entretanto, há resinas cujo processo de cura é catalisado justamente pelo aumento da temperatura. Já outras também precisam ser combinadas com aditivos especiais para que as reações de cura sejam possíveis, ou mesmo para que ocorram em uma velocidade adequada. Esses aditivos são os chamados agentes de cura. Em função de sua composição química, as resinas termofixas podem ser distinguidas em diversas classes. No caso da produção de refratários contendo a carbono, há o predomínio do uso da classe das resinas fenólicas (formadas por reações entre aldeídos e o fenol, ou compostos químicos derivados do fenol) e da classe das resinas furânicas (formadas por reações entre aldeídos e o álcool furfurílico) [16]. Essa preferência se justifica por ambas darem origem a polímeros termofixos que são capazes de gerar grande quantidade de carbono sólido quando pirolisados, como é possível verificar pela Tabela I. Nessa tabela, formada por dados extraídos de duas referências bibliográficas distintas, as faixas de geração de carbono usualmente obtidas para as resinas fenólicas e furânicas podem ser comparadas às faixas comuns ao piche de alcatrão, a outras duas classes de resinas termofixas (epóxi e poliéster insaturada), e à poliacrilonitrila, um polímero 
termoplástico usado na produção de fibras de carbono.

Apesar de haver meios eficazes para favorecer uma maior fixação de carbono para uma dada resina (como, por exemplo, aumentando a densidade de ligações cruzadas formadas durante sua cura), se verifica pela Tabela I que o teor máximo de carbono passível de obtenção ainda varia muito com o tipo de termofixo. Isso se deve à influência de suas características mais intrínsecas, como a configuração molecular e a composição química das unidades repetitivas da estrutura.

Verifica-se, por exemplo, que a presença de oxigênio (principalmente quando em meio à cadeia principal do polímero) e uma maior fração de regiões alifáticas são características que prejudicam a geração de carbono, já que facilitam a ruptura da estrutura polimérica e, portanto, a formação de moléculas voláteis [13, 14]. Já uma configuração molecular mais simétrica favoreceria uma pirólise mais produtiva [14], provavelmente em razão dessa simetria levar o polímero curado a atingir uma estrutura mais densa (menos aberta). Isso então facilitaria tanto a ocorrência das ligações entre os átomos de carbono durante pirólise, como também dificultaria a saída dos voláteis e mesmo as reações com agentes externos (como o oxigênio).

Apesar da produtividade da sua pirólise ser semelhante à obtida com as resinas fenólicas, as resinas furânicas, por exemplo, são mais sensíveis à oxidação justamente pelo maior teor e pela posição dos átomos de oxigênio na sua estrutura curada [13, 14]. Além disso, sua estrutura apresenta maior quantidade de trechos lineares, menor homogeneidade e uma maior concentração de ligações cruzadas duplas [13, 14], as quais, sendo mais reativas que as ligações simples, acabam sendo rompidas com maior facilidade. Algumas dessas características podem ser avaliadas por meio da Fig. 1, que compara dois trechos de estruturas que esses termofixos podem formar.
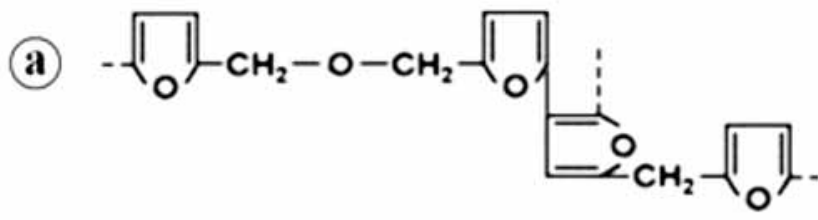

(b)

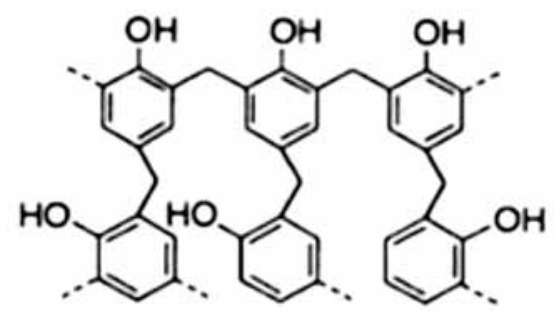

Figura 1: Estruturas moleculares possíveis às resinas (a) furânicas e (b) fenólicas, após a cura [16].

[Figure 1: Possible molecular structures of (a) furan and (b) phenolic resins, after curing [16].]

Desse modo, em vista dessas vantagens intrínsecas à classe das resinas fenólicas, no próximo tópico serão abordados os aspectos principais da sua síntese, cura e de suas propriedades. Em seguida, faz-se uma abordagem geral sobre a importância das características das resinas para o processamento do refratário nas etapas de mistura e de queima, e como os resultados dessa última etapa e o próprio desempenho do refratário em serviço podem ser otimizados pela adição de agentes antioxidantes. Por fim, serão comentados alguns aspectos importantes quanto à toxicidade das resinas termofixas, que devem ser observados atentamente ao longo de todo o processamento do refratário.

\section{Síntese e cura das resinas fenólicas}

As resinas fenólicas são produzidas a partir de reações entre fenóis e aldeídos, funções orgânicas que englobam uma infinidade de compostos químicos. Entretanto, para a produção das resinas comerciais, predomina o uso dos compostos mais simples: o fenol comum (hidroxibenzeno) e o formaldeído (metanal) [16].

As resinas produzidas a partir de outros tipos de aldeídos (acetaldeído, butiraldeído, furfural, etc) não alcançaram grande importância comercial [16]. Já aquelas sintetizadas a partir de alquilfenóis (nos quais um ou mais hidrogênios do anel benzênico do fenol são substituídos por grupos alquis) estariam se tornando mais escassas em razão do seu maior custo e do odor mais forte liberado por esses compostos em comparação ao fenol. Entretanto, fontes mais recentes apontam um forte crescimento na produção de resinas fenólicas sintetizadas a partir do orto-cresol (fenol com um radical metil na posição "orto") [19]. Essas resinas, bem como as derivadas do para- e meta-cresol, encontram suas principais aplicações na indústria de componentes eletrônicos [16, 19]. Na secão Efeito da estrutura molecular da resina fenólica sobre as propriedades do carbono deste artigo, serão analisados alguns estudos encontrados na literatura sobre o comportamento na pirólise de resinas derivadas de alguns alquilfenóis. De acordo com a razão molar entre formaldeído e fenol (F/P = "Formaldehyde"/"Phenol") usada em sua síntese, dois grupos de resinas fenólicas podem ser distinguidos. Quando as quantidades são equimolares ou quando há um excesso de formaldeído $(\mathrm{F} / \mathrm{P} \geq 1)$ tem-se os resóis. Quando o fenol está em excesso $(\mathrm{F} / \mathrm{P}<1)$ são obtidas as novolacas. Além disso, como se verifica na Tabela II, outras diferenças são observadas entre esses dois grupos quanto aos catalisadores usados na síntese, seus grupos funcionais e método de cura. A estabilidade do produto diz respeito ao tempo e às condições nas quais esse pode ser estocado sem que as reações de cura ocorram espontaneamente, o que levaria ao endurecimento precoce da resina.

Os resóis são definidos como misturas entre metilolfenóis, oligômeros diversos (dímeros, trímeros, etc.) e teores residuais de fenol e formaldeído não reagidos [16]. A Fig. 2 mostra as reações que levam à produção dos cinco tipos de metilol-fenóis possíveis aos resóis, pelas quais se verifica que apenas as posições "orto" e "para" do anel benzênico são reativas com o formaldeído. Alguns mecanismos de síntese seletiva são capazes de levar à predominância da ocupação 
Tabela II - Classificação das resinas fenólicas e algumas características básicas (adaptado de [16]).

[Table II - Phenolic resins classification and some characteristics (adapted from [16]).]

\begin{tabular}{ccccccc}
\hline Catalisador & Tipo de resina & $\begin{array}{c}\text { Razão molar } \\
\text { F/P }\end{array}$ & $\begin{array}{c}\text { Estado } \\
\text { físico }\end{array}$ & $\begin{array}{c}\text { Estabilidade do } \\
\text { produto }\end{array}$ & $\begin{array}{c}\text { Grupos } \\
\text { funcionais }\end{array}$ & Método de cura \\
\hline Base & $\underline{\text { Resol }}$ & $\geq 1$ & $\begin{array}{c}\text { Líquido } \\
\text { Sólido }\end{array}$ & Limitado & $\begin{array}{c}\text { Metilol, } \\
\text { fenólico }\end{array}$ & Ácido, base, térmico \\
\hline Ácido & $\underline{\text { Novolaca }}$ & $<1$ & Sólido & Estável & Fenólico & HMTA* temperatura \\
\hline \multirow{2}{*}{ Sal metálico } & $\begin{array}{c}\text { Resol } \\
\text { Novolaca }\end{array}$ & $\geq 1$ & $\begin{array}{c}\text { Líquido } \\
\text { ("high-ortho") }\end{array}$ & $\begin{array}{c}\text { Líquido - limitado } \\
\text { Sólido - estável }\end{array}$ & $\begin{array}{c}\text { Metilol, } \\
\text { fenólico }\end{array}$ & $\begin{array}{c}\text { Resol - ácido, base, térmico } \\
\text { Novolaca - HMTA* } \\
\text { temperatura }\end{array}$ \\
\hline
\end{tabular}

*HMTA = hexametilenotetramina

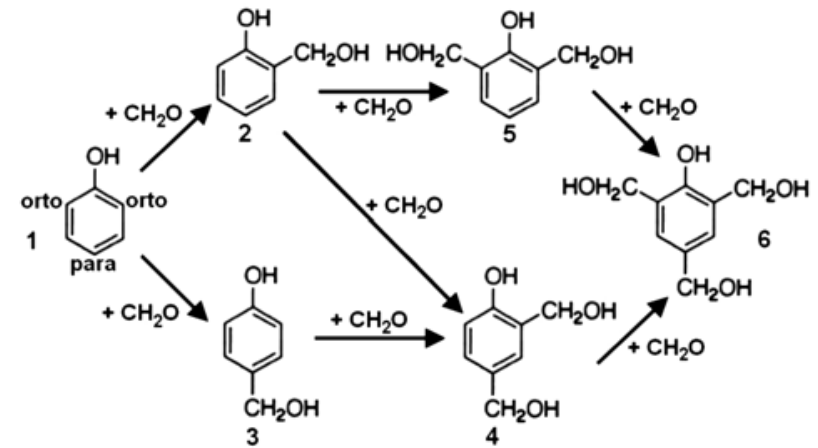

Figura 2: Reações para a formação de metilol-fenóis na síntese de resinas do tipo resol, com formaldeído em excesso e em um meio alcalino (adaptado de [16]).

[Figure 2: Methylol-phenols formation reactions in the resoles synthesis, with formaldehyde in excess and in an alkaline medium (adapted from [16]).]

de uma ou de outra posição do anel, o que então pode afetar significativamente a reatividade e as propriedades da resina final e também após sua cura [16].

As duas reações de condensação que levam à produção dos oligômeros são exemplificadas na Fig. 3, por meio da reação entre os metilol-fenóis 5 e 6 apresentados na Fig. 2. $\mathrm{Na}$ reação $\mathrm{A}$, dois grupos metilóis reagem entre si, formando uma ponte metilênica $\left(-\mathrm{CH}_{2}-\right)$ e liberando uma molécula de água e outra de formaldeído como subprodutos. Essa reação também pode levar à formação de uma ponte do tipo éter $\left(-\mathrm{CH}_{2}-\mathrm{O}-\mathrm{CH}_{2}-\right)$, e nisso não liberar a molécula de formaldeído. Porém, essa ligação é instável e acaba dando origem à ponte metilênica e liberando o formaldeído quando aquecida a mais de $120{ }^{\circ} \mathrm{C}$ [20]. Já na reação $\mathrm{B}$, um grupo metilol reage com o hidrogênio presente nas posições "orto" ou "para" do anel aromático do outro reagente, o que produz uma ponte metilênica entre os dois anéis e libera água como subproduto.

Para ambas as reações, a formação de ligações entre posições "orto" (pontes orto-orto) é dificultada pela maior reatividade das posições "para" do anel aromático, e também pela estabilização dos grupos orto-metilol causada pela proximidade destes com a hidroxila do fenol [16]. Porém, no caso dos resóis produzidos pela catálise com sais metálicos, torna-se possível criar ligações orto-orto e inclusive torná-

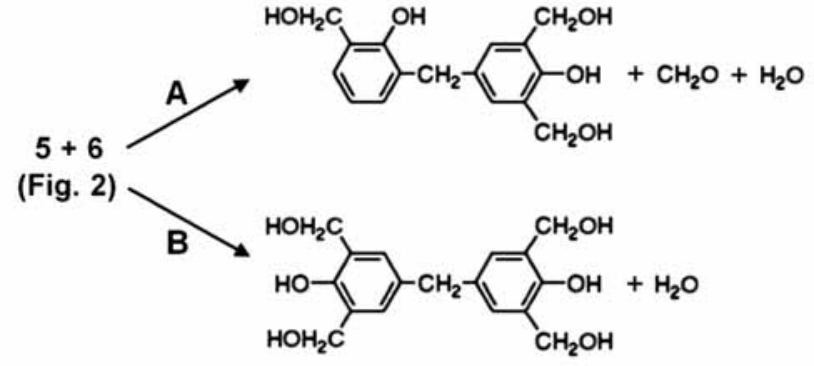

Figura 3: Exemplos de possíveis reações de condensação e cura para os resóis (adaptado de [16]).

[Figure 3: Examples of possible condensation and curing reactions for resoles (adapted from [16]).]

las predominantes (resinas "high ortho").

Na produção de resóis líquidos, permite-se que as reações de condensação ocorram até se atingir moléculas com no máximo dois núcleos aromáticos, enquanto para os resóis sólidos pode-se chegar a três ou quatro núcleos [18]. Para realizar a cura da resina, reações como as exemplificadas na Fig. 3 são retomadas com a mudança do pH do meio (para ácido ou básico) ou com o aumento da temperatura (até 60 a $250{ }^{\circ} \mathrm{C}$, mais usualmente entre 100 e $160{ }^{\circ} \mathrm{C}$ ), formando as efetivas macromoléculas e suas ligações cruzadas [18, 20]. Portanto, esse processo acaba por liberar significativas quantidades de água. A cura dos resóis pelo aquecimento é o método mais comumente usado quando eles são aplicados em refratários [15]. Assim, verifica-se que os resóis não necessitam da adição de um agente de cura, o que é um dos motivos da sua menor estabilidade em comparação às novolacas (Tabela II), sendo indicado condicioná-los em ambientes refrigerados para evitar a cura precoce ao máximo [21].

Passando-se às novolacas, o excesso de fenol em sua síntese logo leva ao início da formação dos oligômeros, os quais costumam apresentar de 2 a 13 núcleos aromáticos, sendo seis núcleos a média usual, o que os torna hidrofóbicos [18]. Por esse motivo, as novolacas puras são encontradas no estado sólido à temperatura ambiente. Os possíveis dímeros formados nas reações de síntese são apresentados na Fig. 4, pelos quais se verifica que, ao contrário dos resóis, as ligações orto-orto são usuais para as novolacas.

No entanto, as ligações orto-para são predominantes nas novolacas mais comuns, representando $50 \%$ das 


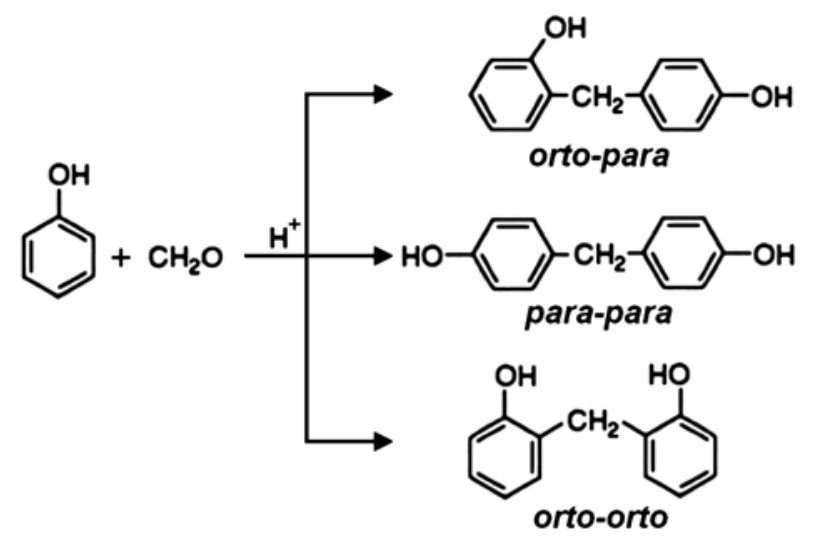

Figura 4: Reações de condensação na produção de resinas novolacas (adaptado de [16]).

[Figure 4: Condensation reactions in production of novolac resins (adapted from [16]).]

ligações entre os anéis aromáticos da resina, enquanto as ligações orto-orto e para-para representam em torno de $25 \%$ cada [16]. Porém, assim como para os resóis, a síntese catalisada com sais metálicos também leva à formação de novolacas "high ortho", as quais apresentam em torno de $57 \%$ de ligações orto-orto, $40 \%$ de ligações orto-para e apenas cerca de 3\% de ligações para-para [16]. Um dos aspectos interessantes dessas resinas "high ortho" é a sua alta reatividade decorrente da grande quantidade de posições "para" não reagidas, o que permite que a cura seja realizada com rapidez [16]. Para a aplicação em refratários contendo carbono, não foram encontradas referências quanto ao desempenho das resinas novolacas ou resóis "high ortho" na sua pirólise. Não possuindo formaldeído livre ou grupos funcionais reativos em seus oligômeros, as resinas novolacas são obtidas como sólidos estáveis, necessitando da adição de um agente de cura e possivelmente de certo aquecimento para que o processo de polimerização seja acelerado. $\mathrm{O}$ hexametilenotetramina (HMTA) é o agente de cura mais aplicado atualmente, havendo outros como bisoxazolinas, bisbenzoxazinas, derivados do fenol e o próprio resol sólido [16]. O HMTA desenvolve complexas reações de cura com a resina, sendo que essas podem ser divididas em dois estágios principais, como está esquematizado na Fig. 5. No primeiro estágio, o HMTA se decompõe e reage com os anéis benzênicos da resina, formando entre eles ligações cruzadas e grupos funcionais nitrogenados. No segundo estágio, esses compostos intermediários de nitrogênio se degradariam para dar origem às pontes metilênicas definitivas do polímero termofixo, e também a outros grupos funcionais secundários como amidas, imidas e iminas. Essas reações foram descritas em detalhes [16].

O início do processo de cura com a decomposição do HMTA começaria a ocorrer efetivamente apenas a temperaturas próximas a $100{ }^{\circ} \mathrm{C}$ [20]. Desse modo, as novolacas poderiam ser previamente misturadas ao HMTA sem que isso prejudicasse significativamente a sua estabilidade à temperatura ambiente. Porém, é esperado que o uso de outros agentes de cura altere esse comportamento, assim como alteraria as próprias reações de cura.

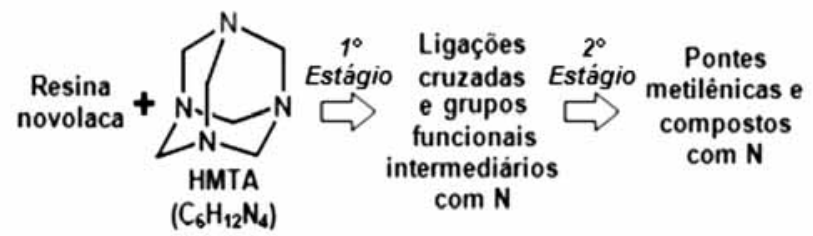

Figura 5: Esquema do processo de cura das novolacas com o uso do HMTA.

[Figure 5: Novolac's curing process steps using HMTA.]

É interessante mencionar que as reações de cura tanto para os resóis como para as novolacas ainda não são completamente compreendidas, o que se deve em muito à dificuldade de se analisar materiais tão complexos em suas estruturas e que não são susceptíveis à fusão ou à solvatação. As novolacas sólidas apresentam seu ponto de amolecimento na faixa de 70 a $100{ }^{\circ} \mathrm{C}$, podendo ser esse valor reduzido pelo aumento do teor de fenol livre na composição [16] (porém, nisso deve-se considerar a toxicidade do fenol). As novolacas também podem ser liquefeitas com o uso de certos solventes, como o etanol, acetona, metanol, isopropanol, $\mathrm{N}, \mathrm{N}$-dimetilformamida, 1,4-dioxano, entre outros [16, 22]. No caso das chamadas novolacas modificadas, essas resinas são sintetizadas por outros métodos ou com outros reagentes além do formaldeído e do fenol. O formaldeído pode ser parcialmente ou totalmente substituído por dialcoóis aromáticos (Fig. 6a), diéteres aromáticos (Figs. 6b e 6c), diolefinas, entre outras substâncias, enquanto o fenol pode ser substituído por naftol (Figs. 6b e 6d), fenóis metiolados, etc. Já a aplicação da catálise com enzimas permite a polimerização isolada de fenóis (materiais denominados como pseudo-novolacas, Fig. 6e), não necessitando haver um segundo reagente [16].

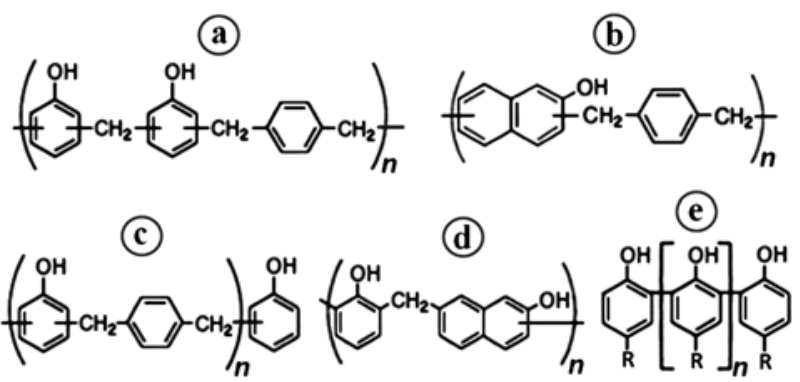

Figura 6: Exemplos das estruturas repetitivas de algumas novolacas modificadas [16].

[Figure 6: Examples of the repetitive structures of some modified novolacs [16].]

É muito possível que o custo dessas resinas já inviabilizaria sua aplicação no campo dos refratários. Porém, seria interessante ao menos analisar como a aromaticidade de suas estruturas interferiria nas propriedades do carbono obtido com a pirólise de seus respectivos polímeros, e 
mesmo como essa característica poderia contribuir para a formação de um carbono mais propenso a grafitizar.

Seguindo a tendência tecnológica atual, a ciência das resinas termofixas também tem se voltado com empenho para o desenvolvimento de estruturas engenheiradas em escala nanométrica. Nesse caminho, ganham destaque os chamados polímeros dendríticos, ou "hyperbranched", uma nova classe arquitetônica de polímeros que possui como característica principal suas macromoléculas altamente ramificadas, cuja estrutura pode variar de randômica a altamente simétrica, como exemplifica a Fig. 7. Apesar de alcançarem elevados pesos moleculares, esses polímeros apresentam-se muito solúveis e atingem uma baixa viscosidade em comparação aos polímeros lineares e ramificados comuns, seja quando solvatados ou quando fundidos, propriedades de grande interesse em termos de processabilidade [23-25].

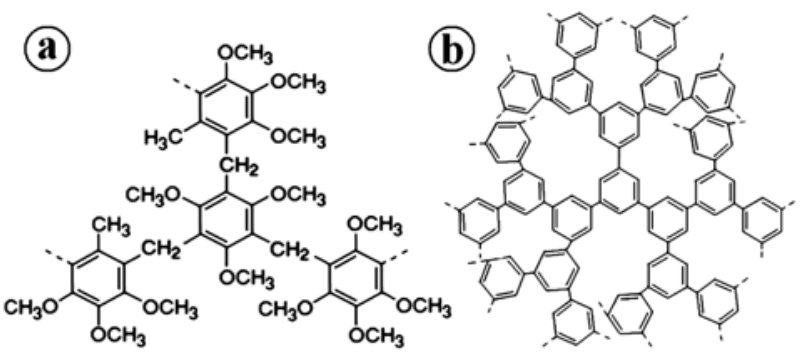

Figura 7: Estruturas parciais de (a) uma resina fenólica [26] e (b) um polifenileno "hyperbranched" (adaptado de [24]).

[Figure 7: Partial structures of (a) an hyperbranched phenolic resin [26] and (b) an hyperbranched polyphenylene (adapted from [24]).]

Dependendo de sua composição, esses materiais são susceptíveis à cura como um termofixo convencional, e também seriam capazes de alcançar excelentes propriedades mecânicas [23-25]. Duas resinas fenólicas distintas com estrutura "hyperbranched" foram produzidas e analisadas, sendo o modelo estrutural de uma delas apresentado na Fig. 7a $[23,26]$. Contudo, apesar de suas propriedades se mostrarem atrativas para o processamento de refratários, ainda é difícil prever qual será o alcance dos polímeros dendríticos para além de áreas como a da nanotecnologia, visto que se trata de um campo de pesquisa ainda muito recente. Portanto, verifica-se que já em meio à diversidade da química das resinas fenólicas ainda podem existir muitos campos a serem explorados na busca por otimizar as propriedades desses materiais para a geração de carbono. Porém, é difícil ter uma noção exata do que já teria sido experimentado em vista da vastidão da literatura e das pesquisas efetuadas em sigilo. Além disso, como já comentado anteriormente, a questão do custo desses materiais sem dúvida é uma das limitações que leva ao predomínio da análise de certos caminhos em detrimento a outros.

Características e propriedades da resina para o processamento do refratário

Como já citado no capítulo de introdução, alguns dos principais atrativos para a substituição do piche pelas resinas termofixas estão nas vantagens que as últimas proporcionam a todas as etapas do processamento do refratário, incluindo sua mistura, conformação e queima. Na etapa de mistura da composição refratária, a viscosidade da resina pode ser considerada como sua característica mais decisiva, já que afeta o tempo de mistura, a capacidade da resina para molhar os componentes do refratário e a capacidade de compactação e fluidez final da composição. $O$ valor da viscosidade também reflete com certa precisão o comportamento que pode ser esperado do termofixo curado na pirólise. As faixas de viscosidade possíveis às resinas são muito amplas, já que dependem de diversos fatores passíveis de controle, tais como a sua distribuição de peso molecular e a presença de solventes. $\mathrm{Na}$ produção de refratários os valores de viscosidade comuns às resinas variam de 500 a $3500 \mathrm{mPa} . \mathrm{s}$ $\left(\right.$ a $20^{\circ} \mathrm{C}$ ) [11]. As resinas de baixa viscosidade são as mais vantajosas para o processamento do refratário. Uma vez que elas conseguem recobrir as partículas da fração sólida com maior eficácia e rapidez, a mistura da formulação é facilitada, permitindo que essa seja feita em um menor tempo e usando equipamentos de menor potência [11]. A capacidade da resina de baixa viscosidade para efetivamente molhar a superfície da fração sólida também é superior, o que evita a segregação de seus componentes durante as etapas de mistura e conformação, algo especialmente crítico quando da presença de "flakes" de grafite em razão da baixa molhabilidade característica desse material [11]. Visto que uma molhabilidade deficiente significa uma menor adesão entre a resina e a fração sólida, tal condição também prejudica o refratário durante a sua queima, pois, com a contração do termofixo a temperaturas elevadas (a partir de $\sim 600{ }^{\circ} \mathrm{C}[14,16]$ ), a baixa adesão facilita a abertura de trincas na interface entre esse e as partículas da composição refratária [8]. Esse comportamento é observado especialmente nas superfícies dos "flakes" de grafite que são paralelas às lamelas da sua estrutura, sendo as arestas dos "flakes" mais propícias para a adesão da resina [8]. Foi colocado que uma boa adesão entre a resina e a fração sólida seria importante tanto para minimizar a expansão do refratário após a liberação da pressão exercida no processo de conformação por prensagem, como também durante a cura da resina (nesse caso, a expansão provavelmente se daria pela pressão exercida pelas inclusões de ar na peça a verde e pelos voláteis liberados pelas reações de cura) [11]. Os menores valores de viscosidade à temperatura ambiente são encontrados tipicamente para os resóis líquidos, visto o baixo peso molecular característico e o significativo teor de água dessas resinas. Porém, a presença da água e a sensibilidade dessas resinas às condições e ao tempo de estoque podem ser problemáticas para a aplicação em refratários [21]. A água é prejudicial não somente quando o composto refratário é passível de sofrer hidratação, como também por limitar o uso e a eficácia dos antioxidantes metálicos e reduzir a densidade final do produto refratário. Tanto para os resóis sólidos como para as novolacas, a viscosidade pode ser reduzida por meio da solvatação ou, considerando a possibilidade de realizar 
o processo de mistura a quente, pelo aquecimento até a temperatura de transição vítrea. No entanto, apesar do uso de solventes favorecer a fluidez a baixas temperaturas, ele também pode acabar prejudicando o acabamento externo do refratário, além de levar à redução da sua densidade [21], pois mesmo os solventes orgânicos não costumam contribuir para a geração de carbono na pirólise [13]. Além da água, os solventes mais comuns adicionados às resinas para a aplicação em refratários seriam o metanol, o etanol, o etileno glicol, a acetona, a metil-etil-cetona e o furfural [21].

A Fig. 8 exemplifica o comportamento da viscosidade de alguns resóis líquidos e novolacas (em solução) com a elevação da temperatura. É interessante avaliar como os valores se diferenciam significativamente à temperatura ambiente $\left(15\right.$ a $\left.30{ }^{\circ} \mathrm{C}\right)$, mas passam a se tornar muito próximos já acima de $35^{\circ} \mathrm{C}$. Isso mostra que a já comentada diferença entre os pesos moleculares médios de resóis e novolacas pode ser compensada com o uso de solventes, e também sugere que aquecimentos sutis já podem afetar sensivelmente a fluidez da resina.

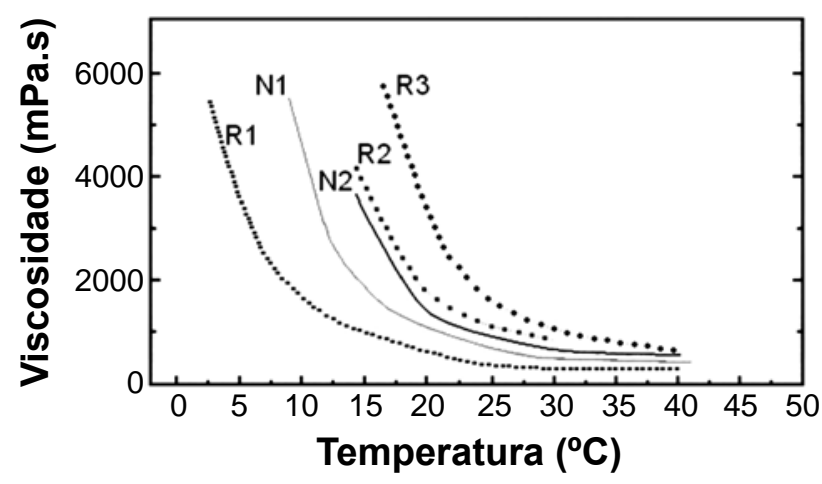

$\mathrm{R}=$ resoles, $\mathrm{N}=$ novolacas em solução

Figura 8: Viscosidade de resóis e novolacas em função da temperatura (adaptado de [11]).

[Figure 8: Resoles' and novolacs' viscosities as a function of temperature (adapted from [11]).]

Quanto às resinas termofixas de alta viscosidade, essas proporcionam uma fluidez inferior à composição refratária final, além de um processo de mistura mais difícil e necessariamente mais prolongado para que se atinja uma condição de molhabilidade similar às das resinas de baixa viscosidade[11,21]. No entanto, háa vantagem da composição refratária final ficar menos adesiva [11], comportamento que deve facilitar os processos de moldagem por compressão e extrusão. Considerando agora as propriedades do refratário, as resinas de alta viscosidade também seriam benéficas por permitirem um maior teor de sólidos na composição, por geralmente atingirem maiores níveis de fixação de carbono durante a pirólise e por formarem um carbono com estrutura menos porosa $[11,21]$. O comportamento do teor de sólidos e da fixação de carbono com a viscosidade da resina são exemplificados nas Figs. 9 e 10, respectivamente, para os casos de novolacas em solução. É visível que o ganho nesses dois parâmetros vai sendo reduzido com o aumento da viscosidade. Portanto, na busca por atingir as melhores propriedades possíveis, é interessante analisar a partir de quais valores de viscosidade as vantagens quanto ao teor de sólidos, à porosidade e quanto à produção de carbono não estariam sendo perdidas pelos prejuízos à processabilidade que uma viscosidade excessiva ocasiona. As resinas de alta viscosidade também podem ser mais problemáticas pela sua maior sensibilidade às mudanças de temperatura, como pode ser deduzido pelos exemplos da Fig. 8. Assim, devese considerar se é possível manter um controle adequado sobre a temperatura, pois, caso contrário, o processamento e, conseqüentemente, as propriedades finais do refratário podem ser prejudicadas [11].

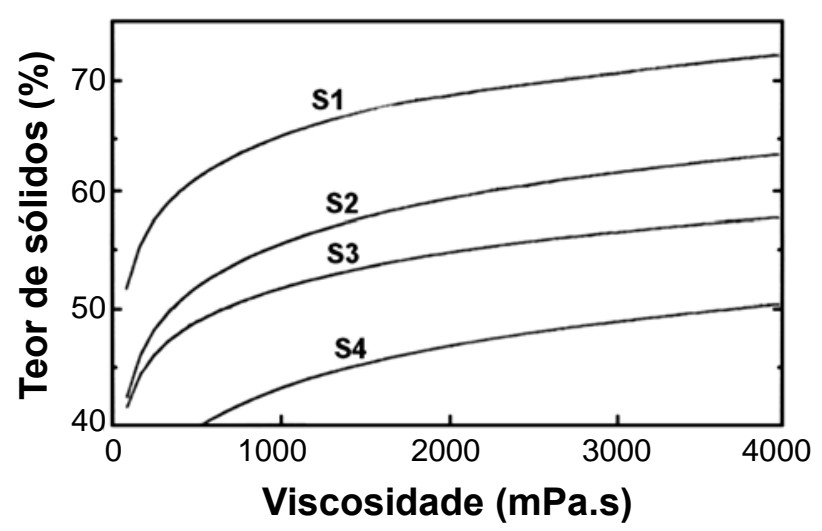

Figura 9: Viscosidade em função do teor de sólidos para quatro resinas novolacas em solução, S1, S2, S3 e S4 (adaptado de [11]). [Figure 9: Viscosity as a function of the solid content for four novolac solutions, S1, S2, S3 e S4 (adapted from [11]).]

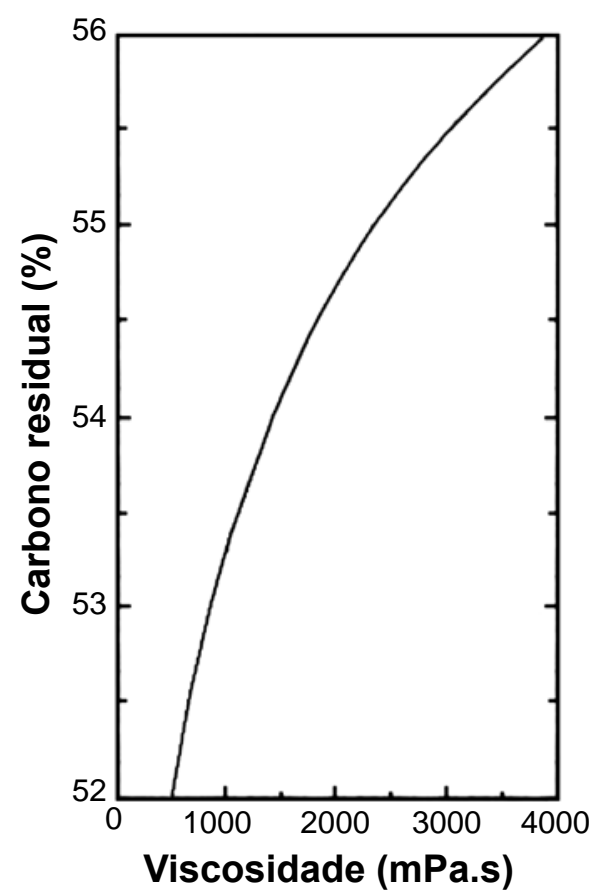

Figura 10: Carbono residual em função da viscosidade de uma resina novolaca em solução (adaptado de [11]).

[Figure 10: Residual carbon as a function of novolac solution viscosity (adapted from [11]).] 
Em conjunto com a resina fluida também é possível adicionar à composição do refratário a resina na forma de pó, o que proporciona o aumento da sua resistência mecânica a verde, a redução da emissão de voláteis e aumento da produção de carbono na pirólise, e a redução da porosidade da estrutura desse carbono [11,16]. A redução da porosidade, por sua vez, leva à melhoria das propriedades mecânicas do refratário, como se pode verificar pela Fig. 11, que apresenta a evolução do módulo de ruptura a frio (MOR, "Modulus of Rupture") e a quente (HMOR, "Hot Modulus of Rupture") de um tijolo refratário em função do acréscimo da resina em pó [11]. Verifica-se como a adição de pequenas quantidades já proporciona ganhos significativos a essas propriedades.

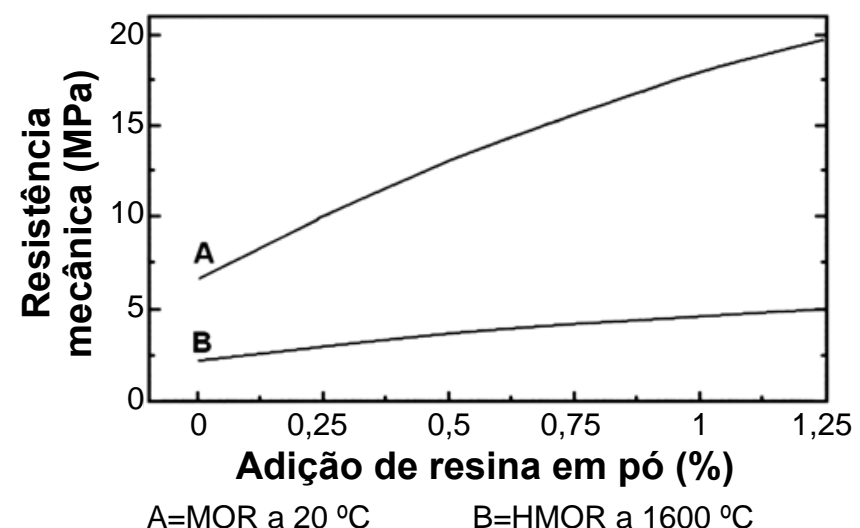

Figura 11: MOR e HMOR de um tijolo refratário em função da adição de resina em pó (adaptado de [11]).

[Figure 11: MOR and HMOR behavior for refractory bricks as a function of its powder resin content (adapted from [11]).]

Para realizar a conformação do refratário é necessário estar atento ao tempo de trabalhabilidade que a resina proporciona, o qual é dependente da velocidade do seu processo de cura. Porém, a determinação desse parâmetro pode ser complexa, já que depende não apenas da resina e do seu método de cura, mas também da temperatura a que essa é submetida e das características do refratário. O controle da cura dos resóis, por exemplo, é dificultada devido ao próprio $\mathrm{pH}$ do refratário [21]. Tanto a cura de resóis como de novolacas (com HMTA) seria acelerada na presença de $\mathrm{CaO}$ e $\mathrm{MgO}$ [8]. No entanto, como era esperado que $\mathrm{pH}$ 's básicos retardassem as reações de cura das novolacas [16], não ficou evidente como esses óxidos básicos poderiam acelerá-las.

Conhecer e ter controle sobre os tempos de trabalhabilidade e de endurecimento do refratário resinado pode ser considerado algo essencial para aproveitar outro grande potencial das resinas termofixas em relação ao piche, que seria a produção de concretos refratários isentos de ligantes inorgânicos, como cimentos.

A substituição dos produtos pré-conformados por concretos é uma importante tendência no setor de refratários, visto as vantagens que os concretos trazem tanto para os seus consumidores como para os seus próprios fabricantes, tais como a eliminação das etapas de moldagem e pré-queima do produto, a agilização da instalação do revestimento e o melhor acabamento da sua superfície externa (principalmente devido à ausência de juntas).

Já é possível encontrar concretos a base de resinas termofixas no mercado atual, mas a aplicação desses produtos ainda seria limitada. Foram apontados como principais problemas para a produção de concretos utilizando resinas termofixas o alto teor necessário destas na composição $(>10 \%$ p) para que se atinja uma fluidez aceitável (o que acaba levando a uma maior porosidade), a dificuldade para dispersar partículas cerâmicas em meio a um líquido orgânico e as já comentadas dificuldades para definir com precisão parâmetros como viscosidade, tempo de trabalhabilidade e o tempo de cura da resina no refratário [27].

\section{Características da resina para a pirólise}

O teor total de carbono gerado com o processo de pirólise pode ser descrito como uma função do equilíbrio entre três variáveis: o teor original de carbono na resina, a produção de voláteis contendo carbono e o retorno desses voláteis ao estado sólido pelos processos de condensação [8]. Como apresenta a Tabela III, o teor inicial de carbono pode variar substancialmente entre os vários tipos de resinas, alcançando seus valores mais elevados em meio às fenólicas.

Tabela III - Teor máximo de carbono na estrutura química de algumas resinas $[13,16]$.

[Table III - Maximum carbon content in the chemical structure of usual resins $[13,16]$.

\begin{tabular}{cc}
\hline & Carbono original (\%p) \\
\hline Resina fenólica & 80 \\
Resina furânicas & 75 \\
Resina epóxi & 75 \\
Resina poliéster insaturada & 60 \\
\hline
\end{tabular}

Nos processos de volatilização e condensação, a presença do oxigênio na atmosfera já se faz muito influente em teores de alguns poucos percentuais, como mostram os resultados da pirólise de uma resina fenólica do tipo resol na Fig. 12, a qual foi aquecida até $1000^{\circ} \mathrm{C}$ em três taxas distintas (rápida, média e lenta), em uma atmosfera inerte ou com $1,5 \%$ de oxigênio. A fixação do carbono cai em quase $20 \%$ pela ação do oxigênio. Desse modo, foi sugerido que o uso da concentração de $1,5 \%$ de oxigênio já seria suficiente para analisar a sensibilidade da resina a atmosferas oxidantes [13, $14,16]$. Quanto à taxa de aquecimento, o efeito desta sobre o carbono produzido mostra-se mínimo, independentemente da atmosfera.

O tamanho e a geometria da peça a ser queimada também podem alterar a capacidade máxima de fixação de carbono, uma vez que grandes dimensões e formatos que propiciem uma baixa área superficial específica significam uma maior dificuldade para que ocorra o escape dos voláteis, tornandoos assim mais susceptíveis a condensar (o que aumentaria a 


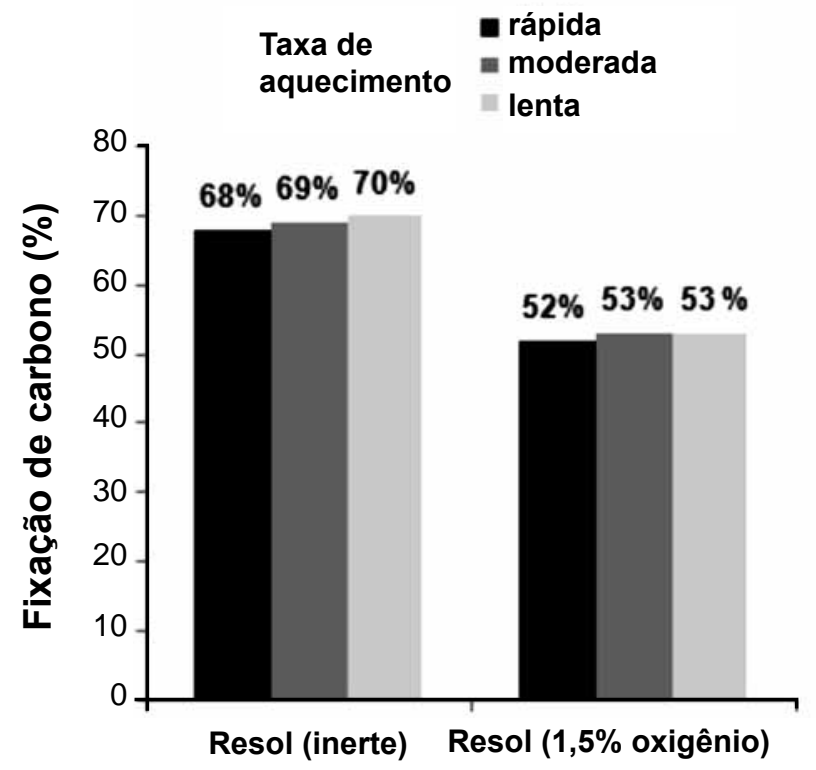

Figura 12: Fixação de carbono na pirólise de uma resina fenólica do tipo resol em função da taxa de aquecimento e da presença de oxigênio na atmosfera (adaptado de [13, 14]).

[Figure 12: Fixed carbon in the pyrolysis of a resol as a function of the heating rate and of the presence of oxygen in the atmosphere (adapted from [13, 14]).]

fixação de carbono). Porém, na presença de oxigênio, essas variáveis deixam de ser tão significativas, pois passa a haver certo predomínio das reações de combustão, prejudicando a ocorrência da condensação [13, 14, 16].

Embora reduza a fixação de carbono, a presença de oxigênio na atmosfera pode levar à formação de whiskers de carbono, os quais, em uma atmosfera com 1,5\% de oxigênio, são maiores e produzidos em maior número para taxas de aquecimentos lentas, não sendo formados com a aplicação de taxas elevadas (as quais levam à redução da emissão de voláteis) $[13,14,16]$. A formação desses whiskers se dá por meio de processos de volatilização e condensação, regidos pela equação de Boudouard (A) $[13,14,16]$.

$$
2 \mathrm{CO}_{(\mathrm{g})} \leftrightarrow \mathrm{C}_{(\mathrm{s})}+\mathrm{CO}_{2(\mathrm{~g})}
$$

Entre as características do polímero termofixo que, justamente por afetarem diretamente a produção de voláteis, são determinantes para o resultado de sua pirólise destacam-se: a densidade de ligações cruzadas, o tamanho e a configuração de suas moléculas antes e após a cura, e a presença de heteroátomos em sua estrutura química $[8,13,14,16]$. A estrutura tridimensional criada pela formação das ligações cruzadas é essencial para uma elevada fixação do carbono [13, $14,16]$, visto que, em comparação a uma estrutura alifática, ela exige a quebra de um maior número de ligações químicas para que moléculas orgânicas de baixo peso molecular sejam liberadas como voláteis. Quando as ligações cruzadas estão em pequena concentração, é possível que compostos de baixo peso molecular contendo carbono já comecem a se volatizar em temperaturas da ordem de $350{ }^{\circ} \mathrm{C}$ [8]. Por outro lado, é interessante analisar que podem ser justamente as ligações cruzadas que dificultam a formação do carbono grafítico a partir da pirólise do termofixo, pois elas reduziriam a liberdade de movimento dos segmentos da macromolécula, impedindo que ocorra uma organização cristalina de longo alcance [8, 28]. No caso do piche, além de inexistirem ligações cruzadas, a aromaticidade das suas moléculas lhes confere tal rigidez que elas apresentam o comportamento de um líquido cristalino (um estado de mesofase), alinhando-se naturalmente conforme ganham mobilidade com a temperatura e, assim, facilitando a formação de lamelas de grafite de grande extensão e nível de perfeição $[5,8]$. No entanto, como será visto no próximo capítulo, ainda há dúvidas sobre o quê realmente impede a formação da estrutura grafítica com a pirólise das resinas, mesmo quando essas são tratadas a temperaturas superiores a $2000{ }^{\circ} \mathrm{C}$. Após a resina passar pelo processo de cura, ainda é possível elevar a densidade de ligações cruzadas da estrutura final através dos processos de pré-oxidação e cloração. Com o tratamento térmico aplicado posteriormente a esses processos, o oxigênio adquirido pela estrutura do termofixo acaba saindo na forma de água, enquanto o cloro é liberado como $\mathrm{HCl}$, causando a desidrogenação da estrutura e, assim, favorecendo a formação de ligações entre os pontos onde antes se encontravam os átomos de hidrogênio [8]. Mesmo com a cura da resina, a sua massa molar inicial média ainda exerce influência sobre a produção de carbono, já que tal característica irá interferir no tamanho e na configuração das macromoléculas após o estabelecimento das ligações cruzadas. Essa interferência é perceptível principalmente quando a atmosfera de queima contém oxigênio, como pode se verificar pela Fig. 13, a qual mostra os resultados da pirólise de resinas novolacas curadas com 10 a $14 \%$ p de HMTA (não se informou a temperatura em que a pirólise foi realizada) $[13,14,16]$.

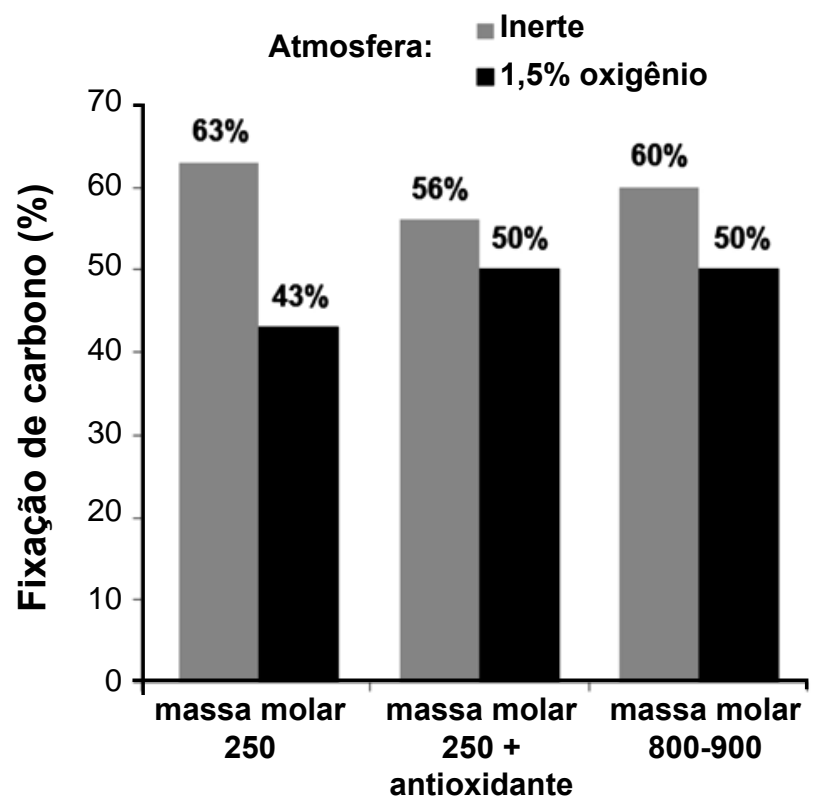

Figura 13: Fixação de carbono em função da massa molar da resina (adaptado de $[13,14,16])$.

[Figure 13: Fixed carbon as a function of the resin molar mass (adapted from [13, 14, 16]).] 
O aumento da massa molar de 250 para a faixa de 800 a $900 \mathrm{~g} / \mathrm{mol}$ reduziu à metade (de 20 para $10 \%$ ) a queda da produção de carbono quando se passou da atmosfera inerte para uma contendo $1,5 \%$ de oxigênio. Essa maior estabilidade à oxidação, seria conseqüência da otimização da rede de ligações cruzadas da estrutura (já que, mantendose constante o teor do agente de cura, o aumento do peso molecular médio significaria um maior número de ligações cruzadas por volume) $[13,14,16]$.

Outro resultado interessante neste gráfico é o efeito do uso de um antioxidante fenólico sobre a resistência à oxidação, visto que sua adição permitiu que a resina com menor peso molecular atingisse uma produção de carbono equivalente à de alto peso molecular com a pirólise sendo realizada em atmosfera oxidante. Esse resultado foi explicado assumindo que esse aditivo teria proporcionado uma estrutura mais uniforme à resina curada, o que então levaria a uma maior resistência à oxidação. Supõe-se que esse antioxidante fenólico seja algum tipo de fenol estericamente impedido, um antioxidante primário muito comum a essas resinas [16].

Quanto aos efeitos dos heteroátomos para a pirólise, já foi mencionado anteriormente os prejuízos decorrentes da presença do oxigênio na composição do termofixo curado. Entre as resinas fenólicas, esse efeito é relevante principalmente para os resóis, visto que a estrutura desses é mais rica em oxigênio quando comparada à das novolacas, sendo possível inclusive a presença de pontes etênicas $[13,14,16]$. Devido a esta característica, os resóis acabam sendo mais sensíveis a atmosferas oxidantes, o que leva sua capacidade de fixação de carbono a ser reduzida em um terço (da faixa de 50 a $70 \%$ p para a faixa de 30 a $50 \%$ p) quando a atmosfera da pirólise muda de inerte para oxidante $[14,16]$. Já no caso das novolacas, como exemplifica a Fig. 13, a queda da fixação de carbono com a alteração da atmosfera pode ser menor, passando de 60 para 50\%p (uma redução de um sexto) no caso das resinas de maior massa molar. Apesar disso, os resóis ainda podem ser capazes de fixar maiores quantidades de carbono do que as novolacas quando estão em meio à estrutura do refratário. Por serem geralmente menos viscosos, os resóis proporcionam uma maior capacidade de compactação à composição refratária, o que pode então levá-la a atingir menores níveis de porosidade. Com isso, a permeação de gases oxidantes pelo refratário é dificultada, aumentando a proteção sobre o carbono. Por esse exemplo, já se verifica como a pirólise da resina isolada pode trazer conclusões enganosas quanto ao seu desempenho para a aplicação em refratários. Pelas informações apresentadas acima e também pelas Figs. 12 e 13 observa-se que, em atmosfera inerte, a produtividade da pirólise dos resóis pode chegar a até $70 \%$ p, enquanto a das novolacas chega a $60 \%$ p. Acredita-se que a explicação para essa diferença resida no fato do processo de cura dos resóis não depender da dispersão de um reagente (como é o caso das novolacas). Isso então permitiria que o termofixo alcançasse uma maior densidade de ligações cruzadas e que essas fossem distribuídas mais homogeneamente por sua estrutura, duas características que são favoráveis à fixação de carbono. Porém, em uma atmosfera oxidante, essas características acabariam por ser contrabalanceadas pela maior sensibilidade dos resóis a tal condição. Ao contrário do oxigênio, o nitrogênio, o boro e o fósforo são heteroátomos que beneficiariam a resistência das resinas fenólicas à oxidação $[13,14,16]$. No entanto, foi apontado que a incorporação direta do boro e do fósforo à resina geralmente não proporciona um efeito estabilizante expressivo [16]. Como será visto no capítulo 4 , o boro (acrescentado como um aditivo) pode atuar como um catalisador da grafitização do carbono, mas esse efeito torna-se significativo apenas com tratamentos térmicos a temperaturas muito elevadas. Essa mesma conclusão foi alcançada em relação ao fósforo que foi incorporado diretamente à estrutura química da resina [29]. Apesar do carbono formado em sua pirólise ser menos resistente à oxidação em comparação ao grafite bruto e ao carbono grafitizável formado pelo piche, os termofixos ainda poderiam proporcionar ao refratário uma maior resistência a esse processo de degradação. Isso porque o uso das resinas pode reduzir a porosidade do refratário, sendo que, a partir de certo teor de carbono, a taxa de oxidação passa a ser determinada não tanto pela resistência química do carbono em si, mas sim pela porosidade aberta da microestrutura refratária $[4,11]$, já que ela permite a penetração de gases oxidantes e proporciona uma elevada área superficial para que estes gases desenvolvam suas reações. Foi inclusive afirmado que a taxa de oxidação do coque formado pelo piche e pelo termofixo são distintas quando estes são analisados isoladamente, mais muito semelhantes nos produtos refratários [4].

Efeito da estrutura molecular da resina fenólica sobre as propriedades do carbono

Entre os artigos internacionais publicados nos últimos trinta anos, foram encontrados apenas três que intencionam investigar com profundidade o efeito da estrutura molecular de resinas fenólicas nas características do carbono gerado com a pirólise desses termofixos $[22,28,30]$. Em um dos trabalhos, os autores estão interessados em compreender esse efeito principalmente para adquirir algum controle sobre a estrutura dos poros do carbono, visto a importância da porosidade para a aplicação desse material nas funções de catalisador, adsorvedor, peneira molecular, entre outras [30]. As resinas fenólicas avaliadas compreenderam um conjunto de resóis preparados pela reação do formaldeído com o fenol comum, com o xilenol 3,5-dimetilfenol e com os para-alquilfenóis para-metilfenol, para-etilfenol, para-npropilfenol e para-isopropilfenol. As estruturas moleculares desses reagentes podem ser comparadas através da Tabela IV.

Como também se verifica pela tabela, as razões molares $\mathrm{F} / \mathrm{P}$ (onde $\mathrm{P}$ agora representa qualquer um dos seis compostos fenólicos) usadas na síntese dessas resinas foram variadas de forma a sempre permitir comparações entre as resinas derivadas do fenol comum com as demais. Como os para-alquilfenóis possuem um sítio reativo a menos em seus anéis aromáticos (o sítio "para"), decidiu-se por 
Tabela IV - Compostos fenólicos aplicados por Lenghaus et al [30] para a síntese de resinas. [Table IV - Phenolic compounds applied by Lenghaus et al [30] for the resins synthesis.]

\begin{tabular}{|c|c|c|c|c|c|c|}
\hline & & Xilenóis & \multicolumn{4}{|c|}{ Para-alquilfenóis } \\
\hline $\begin{array}{c}\text { Estrutura } \\
\text { molecular do } \\
\text { composto fenólico }\end{array}$ & $\stackrel{\mathrm{OH}}{\alpha}$ & $\overbrace{\mathrm{H}_{3} \mathrm{C}}^{\left(\mathrm{CH}_{3}\right.}$ & OH & $\mathrm{CH}_{3}$ & $\mathrm{CH}_{3}$ & $\mathrm{CH}_{\mathrm{HC}}$ \\
\hline $\begin{array}{l}\text { Nome químico } \\
\text { Razões F/P usadas } \\
\text { na síntese das } \\
\text { resinas }\end{array}$ & $\begin{array}{c}\text { Fenol } \\
1,0^{*} \\
1,2 \\
1,8\end{array}$ & $\begin{array}{c}\text { 3,5-dimetilfenol } \\
1,0^{*} \\
1,2\end{array}$ & $\begin{array}{c}\text { Para- } \\
\text { metilfenol }\end{array}$ & $\begin{array}{l}\text { Para- } \\
\text { etilfenol }\end{array}$ & $\begin{array}{c}\text { Para-n- } \\
\text { propilfenol }\end{array}$ & $\begin{array}{l}\text { Para- } \\
\text { isopropilfenol }\end{array}$ \\
\hline
\end{tabular}

* Resinas que não foram curadas antes da pirólise

utilizar duas resinas fenol-formaldeído como referências para as resinas desses reagentes: uma com a mesma razão molar $\mathrm{F} / \mathrm{P}=1,2$, e outra com a razão $\mathrm{F} / \mathrm{P}=1,8$. Essa última foi escolhida por apresentar a mesma proporção entre a quantidade de formaldeído e a quantidade de sítios reativos no anel aromático que a alcançada pelas resinas dos paraalquilfenóis produzidas com a razão $\mathrm{F} / \mathrm{P}=1,2$. As resinas derivadas do 3,5-dimetilfenol ganham destaque em meio a toda classe das resinas fenólicas por serem as únicas que até hoje se mostraram capazes de produzir espontaneamente um carbono grafitizável. Essa capacidade teria sido constatada pelos trabalhos realizados entre as décadas de 50 e 80 [30, 31]. Inclusive, a resina desse xilenol com razão $F / P=1,0$ seria similar à que foi desenvolvida por esses pesquisadores [30]. As resinas de 3,5-dimetilfenol também apresentaram os comportamentos mais atípicos na etapa de síntese. Diferentemente do que ocorreu quando do uso dos outros reagentes, o 3,5-dimetilfenol levou à formação de uma resina já solidificada e pouco solúvel na mistura dos solventes metanol e acetona. De acordo com trabalho que é dedicado exclusivamente à compreensão das resinas derivadas desse composto, a reatividade dele para com o formaldeído seria maior que a do fenol, o que acaba levando à formação de uma resina altamente condensada (ou seja, com moléculas de alto peso molecular) [28]. Porém, suas moléculas apresentariam poucas ligações cruzadas entre si, e teriam uma estrutura predominantemente linear (ao invés de altamente ramificada, como nas resinas fenol-formadeído convencionais) devido às poucas ligações "para-para”. Verifica-se pela Tabela IV que a resina de 3,5-dimetilfenol e com $\mathrm{F} / \mathrm{P}=1,0$ não foi curada antes da pirólise, um procedimento que se acredita ter sido adotado para reproduzir o trabalho de Ouchi e Honda (que não puderam ser consultados por não estarem disponíveis nas bases de dados científicas). Pirolisar a resina sem realizar a cura favoreceria a sua capacidade de grafitização, uma vez que, como já mencionado anteriormente, é muito provável que as ligações cruzadas atrapalhem esse processo [28]. No entanto, o artigo de Lenghaus et al [30] não deixa claro se a cura da resina derivada do 3,5-dimetilfenol e com $\mathrm{F} / \mathrm{P}=1,2$ teria realmente a impedido ou prejudicado sua grafitização em comparação à com $\mathrm{F} / \mathrm{P}=1,0$.

$\mathrm{O}$ método de cura utilizado nesse estudo envolveu um processo de aquecimento de $35 \mathrm{~h}$ até a temperatura máxima de $205{ }^{\circ} \mathrm{C}$. Já a etapa de pirólise foi realizada a $1000{ }^{\circ} \mathrm{C}$ e em uma atmosfera de argônio. Além de características qualitativas, também foram analisadas a capacidade de fixação de carbono de cada resina, bem como a área superficial específica e a estrutura de poros das amostras de carbono (por meio de técnicas de adsorção de $\mathrm{CO}_{2}$ e $\mathrm{N}_{2}$ ). A área superficial específica do carbono tem efeito direto sobre a sua estabilidade térmica e à oxidação, sendo possível esperar que, quanto maior essa área, maior será o prejuízo a essas características. No entanto, essa relação nem sempre pode ficar evidente, possivelmente devido à influência de outros fatores (como inclusive ficou perceptível no trabalho de Lenghaus et al [30], quando foram comparados os comportamentos de perda de massa de resinas que foram carbonizadas tanto como peças inteiras como estando moídas). Quanto à estrutura de poros, são relevantes para as propriedades do carbono não apenas sua quantidade e distribuição de tamanhos, como também os seus formatos. De acordo com referências citadas em [30], na comparação entre poros largos e poros estreitos (ou poros cujas entradas são largas ou estreitas), a presença dos primeiros tende a favorecer a ocorrência de maiores perdas de massa com a pirólise do carbono. Logo após a etapa de cura, Lenghaus et al [30] puderam averiguar que as resinas produzidas com os para-alquilfenóis deram origem a polímeros frágeis, enquanto as resinas sintetizadas com o fenol comum produziram termofixos tenazes e com boa dureza, e isso independentemente da sua razão F/P. Nada foi comentado sobre o comportamento mecânico do termofixo produzido 
pela resina do 3,5-dimetilfenol.

Na pirólise a $1000{ }^{\circ} \mathrm{C}$, os materiais derivados do fenol continuaram apresentando as melhores características para a aplicação em refratários, atingindo os maiores valores de fixação de carbono (50 a 55\%p), baixos valores de área superficial específica e uma microestrutura com poros estreitos. Já entre as resinas derivadas dos para-alquilfenóis, o nível máximo de fixação de carbono foi de $40 \%$ p, porcentagem que foi sendo reduzida até $12 \%$ p conforme aumentava o tamanho do grupo para-alquil do composto fenólico. As suas amostras de carbono também apresentaram os maiores valores de área superficial específica e uma microestrutura com poros predominantemente largos. A resina derivada do 3,5-dimetilfenol $(\mathrm{F} / \mathrm{P}=1,2)$ também demonstrou uma baixa capacidade de fixação de carbono $(30 \% \mathrm{p})$, resultado que não foi informado para o caso da resina com $\mathrm{F} / \mathrm{P}=1,0$. No entanto, para ambas as razões molares, as amostras de carbono produzidas atingiram baixas áreas superficiais específicas e permaneceram com poros largos.

Portanto, os resultados alcançados em [30] sugerem que as resinas fenólicas preparadas com para-alquilfenóis não seriam uma opção interessante para a produção de refratários resinados. Suas propriedades inferiores certamente são decorrentes da redução do número de sítios reativos no anel aromático, o que então teria levado a termofixos com menores densidades de ligações cruzadas, afetando sua resistência pós-cura e reduzindo a produtividade da pirólise. A menor densidade de ligações e, portanto, a estrutura polimérica mais aberta, também pode ser apontada como a causa da maior porosidade do carbono, a qual ficou refletida nos elevados valores de área superficial interna. É provável que resultados semelhantes sejam obtidos na avaliação de outras resinas em que o fenol possuísse seus sítios "orto" ou "para" ocupados por grupos não reativos. Quanto aos sítios "meta", apesar dos resultados negativos alcançados pelo 3,5-dimetilfenol, acredita-se que ainda seria interessante avaliar resinas em que essas posições estejam ocupadas por grupos inertes, principalmente objetivando estimular a grafitização. Mesmo outros testes com o 3,5-dimetilfenol ainda devem ser considerados, pois muitas possibilidades para essa substância aparentam ainda não terem sido analisadas. O 3-metilfenol seria outro composto fenólico favorável à grafitização de acordo com Kobayashi et al [31], que estudaram os carbonos obtidos de resinas fenólicas sintetizadas com o fenol comum, com o 3-metilfenol e com 3,5-dimetilfenol. Os resultados da análise por difração de raios $\mathrm{X}$ das amostras tratadas a 1000 e $2000{ }^{\circ} \mathrm{C}$ são apresentados na Fig. 14 por meio dos difratogramas da região em torno de $2 \theta=26,5^{\circ}$, ângulo da linha de difração característica dos planos 002 da estrutura lamelar do grafite.

Analisando as amostras tratadas a $2000{ }^{\circ} \mathrm{C}$, logo é possível confirmar a capacidade de grafitização do carbono derivado da resina de 3,5-dimetilfenol, visto que o pico de difração atingiu grande intensidade e ficou muito próximo ao ângulo de $26,5^{\circ}$. Já quanto ao carbono da resina de 3-metilfenol, apesar do seu pico de difração ocorrer a $25^{\circ}$

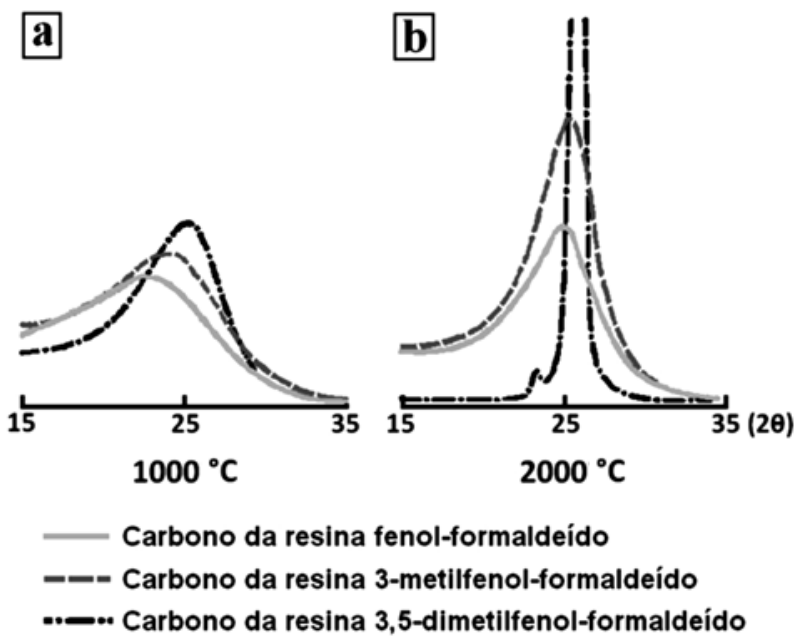

Figura 14: Difratogramas de raios $\mathrm{X}$ dos carbonos obtidos de três tipos de resinas fenólicas, após tratamento a (a) $1000{ }^{\circ} \mathrm{C}$ e (b) 2000 ${ }^{\circ} \mathrm{C}$ (adaptado de [31]).

[Figure 14: X-ray diffraction patterns for the carbon samples obtained from three kinds of phenolic resins, treated at (a) $1000{ }^{\circ} \mathrm{C}$ and (b) $2000{ }^{\circ} \mathrm{C}$ (adapted from [31]).]

(o que significa uma distância interplanar superior à que caracteriza o grafite), a maior intensidade que ele alcança em comparação ao pico do carbono da resina fenol-formaldeído já possibilita concluir que o primeiro seria mais susceptível à grafitização do que o segundo, embora isso não seja suficiente para classificá-lo como grafitizável. Entretanto, não foi possível confirmar se Kobayashi et al realizaram a cura dessas resinas antes da pirólise, pois o procedimento para a preparação das mesmas também está descrito em artigos dos pesquisadores Ouchi e Honda que não se encontram disponíveis. Passando ao trabalho de Costa et al [22], este se diferencia dos demais vistos até o momento por analisar o efeito da alteração do composto fenólico (utilizando o fenol, o 3-metilfenol e o para-metilfenol) sobre o comportamento da pirólise de novolacas. Porém, acaba sendo difícil aproveitar as conclusões desse estudo, pois o artigo dá a entender que nenhuma das resinas teria sido curada antes da carbonização (tanto que não se mencionou o uso de qualquer agente de cura, como o HMTA). Apesar disso, nele são feitas importantes observações quanto às significativas diferenças que podem surgir entre os resultados da pirólise realizada em meio inerte e em meio oxidante. Essas observações novamente reforçam a idéia de que atmosferas inertes devem ser evitadas para a avaliação da pirólise dos termofixos, pois elas podem levar a comportamentos completamente opostos aos que ocorreriam na presença de oxigênio (que seria condição mais usual para os refratários aplicados à siderurgia). Uma possibilidade que aparenta não ter sido avaliada pela literatura até o momento (embora tenha sido considerada por Lenghaus et al [30]) é a combinação de mais de um tipo de composto fenólico para a síntese da resina termofixa. Duas combinações interessantes seriam, por exemplo, o fenol comum com o 3,5-dimetilfenol ou com o 3-metilfenol. É possível supor que ambas poderiam 
favorecer a grafitizabilidade do termofixo, ao mesmo tempo em que evitariam alguns inconvenientes, como o da condensação excessiva da resina sintetizada apenas com o 3,5-dimetilfenol. Não foram encontrados na literatura quaisquer motivos que impedissem tais combinações.

\section{Aditivos aplicados às resinas na produção de refratários: agentes antioxidantes}

Além dos agentes de cura, outros aditivos comuns às resinas usadas na fabricação de refratários são os agentes antioxidantes, cuja função principal é reduzir a susceptibilidade à oxidação do carbono formado com a pirólise do polímero termofixo [16, 32]. Tais aditivos englobam principalmente substâncias inorgânicas como pós metálicos ( $\mathrm{Al}, \mathrm{Mg}$, $\mathrm{Si}$ e ligas metálicas), carbetos ( $\mathrm{SiC}$ e $\left.\mathrm{B}_{4} \mathrm{C}\right)$ e boretos $\left(\mathrm{ZrB}_{2}, \mathrm{MgB}\right.$ e $\left.\mathrm{CaB}_{6}\right)$, devendo a escolha entre eles ser feita em função da composição do refratário e também das condições de serviço as quais esse será submetido [32]. O teor dos antioxidantes nas composições refratárias costuma ficar em torno de 3 a $5 \%$ em peso, sendo comum e muito vantajoso que se utilizem combinações de dois ou mesmo três tipos diferentes desses aditivos, uma vez que cada um pode atuar por mecanismos e em faixas de temperatura distintas, proporcionando assim uma proteção mais completa ao refratário [32].

Quanto a esses mecanismos de atuação, destacamse como os principais aqueles em que o antioxidante age [32]: reagindo diretamente com o carbono para a formação de carbetos, os quais são mais resistentes à oxidação que o próprio carbono; reagindo com o $\mathrm{CO}$ da atmosfera de forma a recuperar o carbono sólido; reduzindo a porosidade do refratário em decorrência das reações que levam a produtos com maior volume específico; formando uma camada protetora sobre a superfície quente do refratário; e formando compostos que beneficiam a resistência mecânica e a resistência à corrosão (como whiskers de $\mathrm{AlN}$ e $\mathrm{SiC}$, e $\mathrm{MgAl}_{2} \mathrm{O}_{4}$ ).

Os antioxidantes do tipo pó metálico atraem grande interesse por seu baixo custo e por beneficiarem não apenas a resistência à oxidação como também a resistência mecânica e à erosão do refratário [11, 21, 32]. No entanto, os teores passíveis de adição bem como a eficácia desses pós podem ser limitados pela sua alta reatividade com a água que esteja presente na composição do refratário, isso já durante a sua etapa de processamento, o que então diminuiria a atuação desses aditivos a altas temperaturas. O recobrimento dos pós metálicos com óxidos é recomendado para reduzir esse problema, embora ainda não tenha sido desenvolvida uma técnica de recobrimento completamente eficaz [32]. Nesse ponto é interessante ressaltar que as resinas fenólicas podem apresentar teores muito significativos de água na sua composição, além de também poderem formá-la durante suas reações de cura, dois aspectos especialmente significativos para as resinas do tipo resol. O uso de ligas metálicas em lugar dos metais puros aparenta trazer muitas vantagens, uma vez que o mecanismo de ação das ligas seria equivalente à combinação dos mecanismos de cada metal, inclusive com cada um atuando em sua temperatura característica [32]. As ligas de alumínio e magnésio, por exemplo, têm proporcionado aos refratários um desempenho superior quando comparadas aos dois metais usados isoladamente [32]. Quanto ao alumínio, uma importante desvantagem do seu uso como antioxidante está na formação do $\mathrm{Al}_{4} \mathrm{C}_{3}$, um carbeto que se hidrata com facilidade e que, nessa reação, sofre significativas expansões volumétricas. Assim, se exposto por tempos prolongados a ambientes úmidos, o refratário fica susceptível a desenvolver trincas. No entanto, esse problema pode ser reduzido pela combinação do $\mathrm{Al}$ com antioxidantes do tipo carbeto, de forma a produzir compostos mais complexos, como o $\mathrm{Al}_{8} \mathrm{~B}_{4} \mathrm{C}_{7}$ e $\mathrm{Al}_{4} \mathrm{SiC}_{4}$, os quais são mais resistentes à hidratação e continuam atuando como antioxidantes [32]. Sobre a classe dos carbetos antioxidantes, o carbeto de silício age de forma semelhante à do silício metálico, mas esse último seria mais eficiente por permitir a formação de uma maior quantidade da fase $\mathrm{Mg}_{2} \mathrm{SiO}_{4}$, responsável por bloquear a porosidade do refratário. Já o $\mathrm{B}_{4} \mathrm{C}$ age reduzindo o $\mathrm{CO}$ gasoso e, principalmente, estimulando a formação de uma densa camada de óxido sobre a superfície quente do refratário, prevenindo sua oxidação. Porém, além de caros, os antioxidantes a base de boro formariam fases líquidas a altas temperaturas que prejudicariam a resistência mecânica e à corrosão do refratário, problemas que também são comuns aos antioxidantes da classe dos boretos [32]. Ainda assim, a combinação entre o pó de $\mathrm{Al}$ e $\mathrm{B}_{4} \mathrm{C}$ tem se mostrado como uma das mais eficientes para reduzir o problema da oxidação do carbono [32].

Embora menos resistente à oxidação em comparação ao carbono obtido a partir do piche, o carbono não grafitizável formado na pirólise dos termofixos possui a vantagem de ser mais reativo que o primeiro para com os aditivos antioxidantes mencionados até o momento, como no caso das reações que levam à formação de carbetos [11]. Acreditase que essa maior reatividade também seria decisiva para que os antioxidantes formem algumas estruturas especiais, como os whiskers com formato de alteres ("dumbbellshaped") estudados nos trabalhos de Aneziris et al [6,7,33, 34], os quais proporcionariam ao refratário propriedades termomecânicas muito superiores às obtidas quando da formação dos whiskers aciculares comuns.

$\mathrm{Na}$ seção Características da resina para a pirólise deste artigo foi comentado o efeito positivo que a adição de um antioxidante orgânico (possivelmente um fenol estericamente impedido) teve sobre a fixação de carbono de um polímero termofixo. No entanto, não foram encontrados quaisquer trabalhos que aplicassem ou mesmo cogitassem o uso desses antioxidantes nas resinas utilizadas em refratários.

Características da resina quanto à toxicidade $e$ comparação geral entre resóis e novolacas

Apesar da quantidade e da toxicidade de suas emissões durante a pirólise serem mínimas em comparação às liberadas pelo piche, a aplicação das resinas fenólicas ainda 
pode representar riscos à segurança ocupacional e ambiental se elas não forem utilizadas de maneira adequada. $\mathrm{Na}$ análise desses riscos potenciais, destacam-se como fatores a serem averiguados os teores de fenol e formaldeído livres na composição da resina e, se for o caso, as características de seu solvente [11]. O fenol livre é especialmente crítico para o caso dos resóis líquidos. Embora teores acima de $5 \%$, segundo algumas normas internacionais, já levem à classificação da resina como tóxica [11], ainda é comum encontrar no mercado resóis com cerca de $20 \%$ p de fenol livre. Já quanto às resinas fenólicas sólidas e às novolacas em solução, essas não costumam apresentar mais do que $1 \%$ p de fenol livre, o que as classificaria como atóxicas quanto a essa característica [11]. Já o formaldeído livre costuma ficar dentro da faixa de concentração considerada como atóxica para qualquer tipo de resina fenólica [11]. No uso de solventes, como no caso das soluções de novolacas, além do seu poder de dissolução também é preciso estar atento

Tabela V - Resumo das principais características de resóis e novolacas e de seus efeitos para a aplicação em refratários. [Table V-Summary of resols and novolacs main characteristics and their effects for the application in refractories.]

\begin{tabular}{|c|c|c|c|}
\hline & & $\underline{\text { Resóis }}$ & $\underline{\text { Novolacas }}$ \\
\hline & Razão F/P & $\geq 1,0$ & $<1,0$ \\
\hline \multicolumn{2}{|c|}{ Métodos de cura } & $\mathrm{pH}$ e/ou aquecimento & Agente de cura + aquecimento \\
\hline \multicolumn{2}{|r|}{ Estabilidade } & $\begin{array}{c}\text { Limitada } \\
\text { - Condicionamento a baixa } \mathrm{T} \\
\text { - pH do meio pode levar à cura }\end{array}$ & Estável \\
\hline & Toxicidade & $\begin{array}{c}\text { Maior } \\
\text { - Devido ao teor de fenol livre }\end{array}$ & Menor \\
\hline \multirow{4}{*}{ 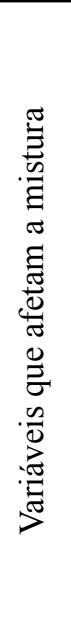 } & $\begin{array}{l}\text { Peso molecular } \\
\text { (PM) usual }\end{array}$ & Menor ( 2 a 4 anéis aromáticos) & Maior (média de 6 anéis aromáticos) \\
\hline & $\begin{array}{l}\text { Viscosidade } \\
\text { usual da resina }\end{array}$ & $\begin{array}{l}\text { Baixa } \\
\text { - Favorece uma maior molhabilidade e } \\
\text { • menor tempo/energia para a mistura } \\
\text { • Favorece a compactação da composição } \\
\text { refratária e, portanto, uma menor porosidade }\end{array}$ & $\begin{array}{c}\text { Alta } \\
\text { - Favorece um maior teor de } \\
\text { - sólidos na composição refratária } \\
\text { - Pode ser reduzida com o uso de } \\
\text { - solventes, temperatura e menor PM. }\end{array}$ \\
\hline & $\begin{array}{l}\text { Reatividade } \\
\text { com os óxidos } \\
\text { refratários }\end{array}$ & $\begin{array}{c}\text { Maior } \\
\text { - O MgO aceleraria as reações de cura } \\
\text { - A água usada como solvente ou liberada na } \\
\text { cura pode hidratar o } \mathrm{MgO}\end{array}$ & $\begin{array}{c}\text { Menor } \\
\text { •A liberação de água seria mínima }\end{array}$ \\
\hline & Processo de cura & $\begin{array}{l}\text { - Sensível ao pH do meio } \\
\text { - Sensível já a } \mathrm{T}<100^{\circ} \mathrm{C}\end{array}$ & - Com HMTA, ocorre a $\mathrm{T} \geq 100{ }^{\circ} \mathrm{C}$ \\
\hline \multirow{4}{*}{ 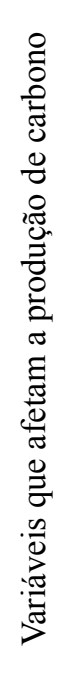 } & $\begin{array}{l}\text { Peso molecular } \\
\text { (PM) usual }\end{array}$ & Baixo & $\begin{array}{c}\text { Alto } \\
\text { • Favorece a fixação de C } \\
\text { • A redução do PM pode ser compensada } \\
\text { - pelo aumento do teor do agente de cura }\end{array}$ \\
\hline & $\begin{array}{l}\text { Viscosidade } \\
\text { usual da resina }\end{array}$ & $\begin{array}{c}\text { Baixa } \\
\text { • Favorece a fixação de C por reduzir a } \\
\text { porosidade do refratário, o que o torna menos } \\
\text { permeável a gases oxidantes }\end{array}$ & $\begin{array}{c}\text { Alta } \\
\text { • Favorece a fixação de C e também a obtenção } \\
\text { de uma matriz carbonácea menos porosa } \\
\text { (menos permeável a gases oxidantes) }\end{array}$ \\
\hline & $\begin{array}{l}\text { Presença de } \mathrm{O} \text { no } \\
\text { polímero }\end{array}$ & $\begin{array}{c}\text { Maior } \\
\bullet \text { Prejudica a fixação de C }\end{array}$ & Menor \\
\hline & $\begin{array}{l}\text { Produção usual } \\
\text { de voláteis }\end{array}$ & $\begin{array}{c}\text { Maior } \\
\text { - Devido ao fenol livre e à quebra das ligações } \\
\text { para a saída do } \mathrm{O}\end{array}$ & Menor \\
\hline
\end{tabular}


a características como sua pressão de vapor, toxicidade e inflamabilidade, devendo-se considerar que todas elas têm certa dependência para com a temperatura [11].

É interessante observar que alguns componentes da composição do refratário podem auxiliar a reduzir as emissões das resinas. Os óxidos de magnésio e cálcio, por exemplo, podem neutralizar o fenol livre, enquanto a presença de negro de fumo reduziria a emissões na pirólise de resinas novolacas, comportamento que foi atribuído à interação dos voláteis com a superfície das partículas dessa fonte de carbono [8]. Quanto à composição dessas emissões, Gardziella et al [14] a apresenta em detalhes para o caso da pirólise de uma resina fenólica em atmosfera oxidante. A partir de $350^{\circ} \mathrm{C}$, verificouse a evolução predominante de água, hidrogênio, monóxido de carbono e hidrocarbonetos de baixo peso molecular. Acima de $450{ }^{\circ} \mathrm{C}$, também passam a surgir compostos fenólicos e aromáticos, entre os quais se incluem o benzeno e pequenas quantidades de alguns hidrocarbonetos policíclicos aromáticos (HPA's), como o naftaleno, o antraceno, o fenantreno, o fluoranteno e o pireno. No entanto, além de todos terem sido liberados em quantidades mínimas, nenhum desses HPA's é considerado cancerígeno pela Agência Internacional de Pesquisas sobre o Câncer [35]. Assim, pode ser julgada incorreta ou incompleta a afirmação de que a pirólise dos polímeros termofixos não leva à liberação de HPA's, sendo mais apropriado declarar que os HPA's são produzidos em quantidades mínimas e que os tipos liberados não são considerados nocivos, ao contrário dos HPA's produzidos na carbonização do piche, como o benzopireno. Assim, reunindo as principais informações coletadas nesse capítulo sobre as diferenças entre resóis e novolacas, organizou-se a Tabela $\mathrm{V}$ para facilitar a comparação das principais características e comportamentos esperados para essas resinas. Logo se verifica que as novolacas agregariam um maior número de vantagens, principalmente considerando-se sua aplicação em refratários formados por óxidos susceptíveis à hidratação, como o MgO. Porém, mesmo neste caso, os benefícios ligados às baixas viscosidades dos resóis ainda justificam a dificuldade que surge quando é necessário fazer uma opção entre essas duas classes de resinas. Além disso, também se deve considerar que o uso de solventes e de certos aditivos pode modificar as tendências assinaladas.

\section{Estrutura do carbono não grafitizável}

Embora seja muitas vezes designado como amorfo, o carbono obtido da pirólise dos polímeros termofixos na verdade já apresenta alguma organização cristalográfica bidimensional de curto alcance (limitada à escala nanométrica). Portanto, o correto é defini-lo pelo termo não grafítico, uma vez que a estrutura efetivamente amorfa não deve possuir qualquer organização bidimensional com extensão superior a $1,0 \mathrm{~nm}$ [36]. A estrutura não grafítica também surge quando o processo de cristalização de carbonos grafitizáveis não é completado. Por exemplo, na pirólise do piche, segundo Rand e McEnaney [8], as dimensões dos cristalitos lamelares não vão muito além dos $5 \mathrm{~nm}$ para tratamentos a temperaturas da ordem de $1500{ }^{\circ} \mathrm{C}$, sendo que somente a partir dos $2000{ }^{\circ} \mathrm{C}$ o crescimento dessas unidades passaria a ser mais intenso. Portanto, na faixa de temperaturas usual para o processamento do aço, Rand e McEnaney afirmam que tanto o carbono derivado das resinas como o do piche seriam estritamente não grafiticos. Apesar disso, a essas temperaturas, os cristalitos lamelares formados por fontes grafitizáveis como o piche já podem se encontrar bastante alinhados e empacotados entre si, o que proporciona ao carbono não grafítico propriedades macroscópicas mais próximas às do grafite, além de baixa porosidade e baixa área superficial (inferior a $3 \mathrm{~m}^{2} / \mathrm{g}$ [37]). Esse alinhamento e empacotamento podem ser observados na Fig. 15a, que apresenta a micrografia obtida por microscopia eletrônica de transmissão de alta resolução (HRTEM, "HighResolution Transmission Electron Microscopy") de uma amostra de antracita (fonte de carbono grafitizável) tratada a $1000{ }^{\circ} \mathrm{C}$.
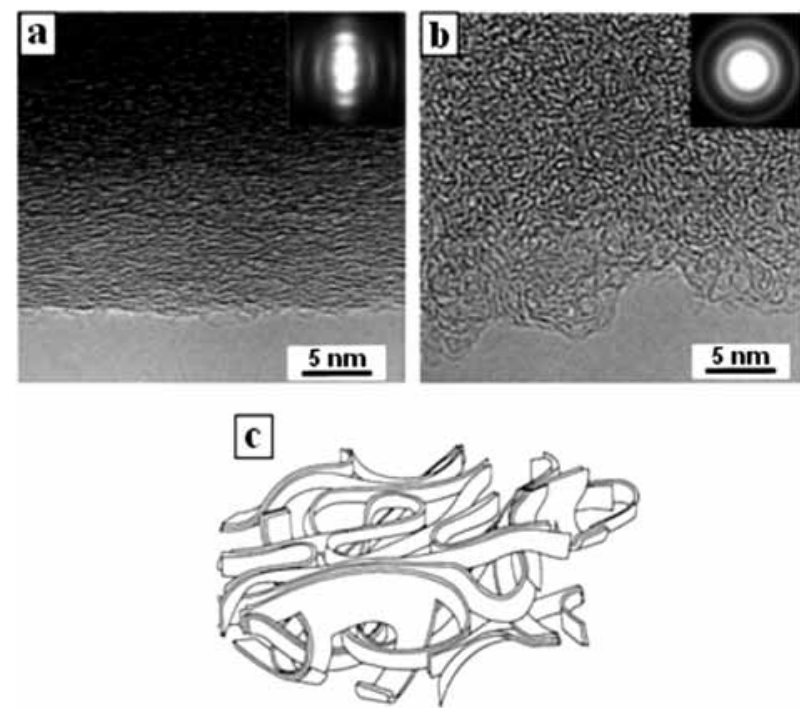

Figura 15: Imagens de HRTEM e padrões de difração de amostras de (a) sucrose e (b) antracita, tratadas a $1000{ }^{\circ} \mathrm{C}$, e (c) modelo de Ban, Crawford e Marsh para o carbono não grafitizável [9].

[Figure 15: HRTEM images and diffraction patterns of (a) sucrose and $(b)$ anthracite samples, treated at $1000{ }^{\circ} \mathrm{C}$, and (c) nongraphitizing carbon model of Ban, Crawford e Marsh [9].]

Já na pirólise de fontes não grafitizáveis, os pequenos conjuntos de lamelas empilhadas do carbono não grafítico permanecem sem qualquer orientação preferencial, formando uma estrutura aberta tal como na amostra de carbono apresentada na Fig. $15 \mathrm{~b}$ (obtida pelo tratamento a $1000{ }^{\circ} \mathrm{C}$ do composto orgânico sucrose). Nesse caso, o carbono não grafítico acaba possuindo grande quantidade de poros, elevada área superficial (que pode ultrapassar os $500 \mathrm{~m}^{2} / \mathrm{g}$ [37]) e propriedades muito distantes das do grafite.

Apesar das avançadas técnicas analíticas existentes atualmente, ainda não se teria chegado a um consenso sobre os motivos que impedem os carbonos não grafitizáveis de cristalizar mesmo quando tratados a temperaturas acima de $3000{ }^{\circ} \mathrm{C}$. Afinal, em teoria, esse processo seria termodinamicamente favorável em decorrência da grande 
redução da energia livre que seria causada pela diminuição da área superficial da estrutura do carbono.

Segundo Harris [9], os modelos tridimensionais de lamelas torcidas que já foram criados para representar o carbono não grafitizável (como o de Ban, Crawford e Marsh, mostrado na Fig. 15c) seriam inconsistentes para explicar esse comportamento, isso em razão da grande flexibilidade que caracteriza essas lamelas quando elas são compostas exclusivamente por anéis hexagonais de carbono. Tal flexibilidade permitiria que o empacotamento entre as lamelas evoluísse à medida que a temperatura fosse elevada, produzindo a estrutura grafítica. Partindo desse fato, Harris propõe que a explicação para a incapacidade de cristalização do carbono não grafitizável estaria na presença de anéis de carbono não-hexagonais em sua estrutura, o que então permitiria a formação de dobras nas lamelas que seriam estáveis mesmo a temperaturas muito elevadas. Inclusive, esse comportamento também é observado em estruturas do carbono descobertas mais recentemente, que são os nanotubos, os fulerenos e as nanopartículas de carbono.

$\mathrm{Na}$ Fig. 16a, por exemplo, dois anéis pentagonais de carbono são indicados por setas no modelo do fulereno $\mathrm{C}_{540}$. No caso das nanotubos, os anéis de carbono não-hexagonais seriam encontrados em suas extremidades justamente para permitir o fechamento destas, como na posição indicada pela seta no nanotubo múltiplo apresentado na Fig. $16 \mathrm{~b}$.

Já a Fig. 16c apresenta a micrografia do carbono obtido com o tratamento a $2600{ }^{\circ} \mathrm{C}$ de uma amostra de policloreto de vinilideno, na qual se verifica estruturas similares a nanopartículas de carbono (que podem ser definidas como fulerenos concêntricos). Partindo disso, Harris supõe que carbonos não grafitizáveis submetidos a temperaturas não

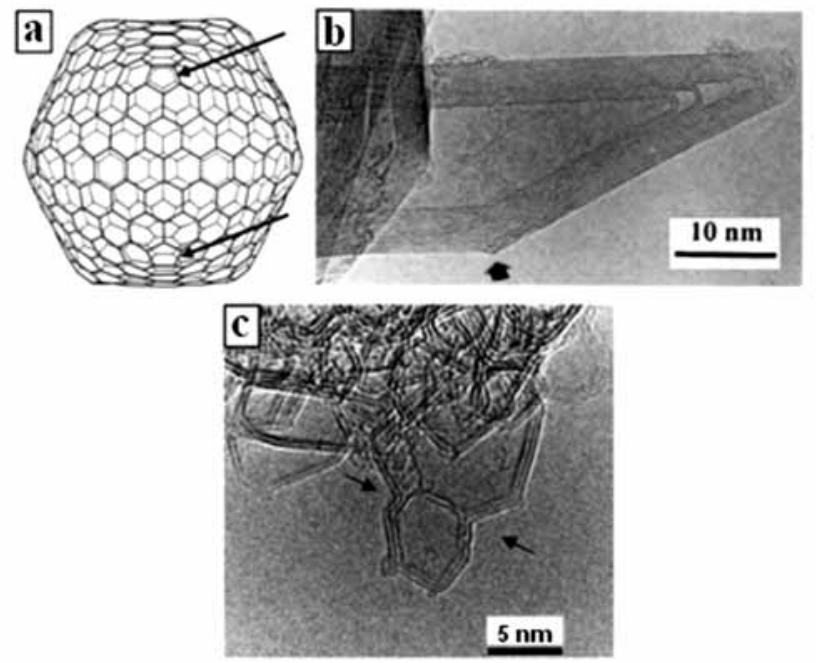

Figura 16: (a) Modelo do fulereno icosaedral $\mathrm{C}_{540}$ e imagens de HRTEM da (b) extremidade de um nanotubo múltiplo e (c) do carbono obtido do policloreto de vinilideno e tratado a $2600{ }^{\circ} \mathrm{C}$ (adaptado de [9]).

[Figure 16: (a) Icosahedral $C_{540}$ fullerene model and HRTEM images of $(b)$ a multiple nanotube cap and of $(c)$ a polyvinylidene chloride derived carbon heated at $2600{ }^{\circ} \mathrm{C}$ (adapted from [9]).] tão elevadas (como na Fig. 15b) apresentariam estruturas pré-fulerênicas, mas admite a dificuldade em se obter provas visuais disso através das imagens de HRTEM. Porém, seu artigo cita trabalhos de outros pesquisadores que, por meio da espectroscopia Raman, teriam encontrado evidências claras da presença dessas estruturas no carbono derivado da sucrose, tratado a temperaturas entre 1000 e $2300^{\circ} \mathrm{C}$. Assim, baseado nessas correlações e resultados, Harris reapresenta o seu modelo teórico para o carbono não grafitizável, mostrado na Fig. 17a, o qual já havia sido proposto em um artigo de 1997 [38]. Nesse modelo, descreve-se uma estrutura constituída por fragmentos discretos de folhas de carbono curvadas, que conteriam anéis pentagonais e heptagonais dispersos em suas estruturas. As efetivas unidades fulerênicas estariam se formando apenas a temperaturas muito elevadas, como no caso do chamado carbono vítreo, uma classe especial de carbonos não grafitizáveis obtida com tratamentos a temperaturas da ordem de até $3000{ }^{\circ} \mathrm{C}$ e cujo modelo é apresentado na Fig. $17 \mathrm{~b}$.

Sendo os modelos propostos por Harris realísticos, a grafitização do carbono derivado dos polímeros termofixos dependeria de encontrar meios para evitar a formação desses anéis não-hexagonais ou de desmanchá-los de algum modo.
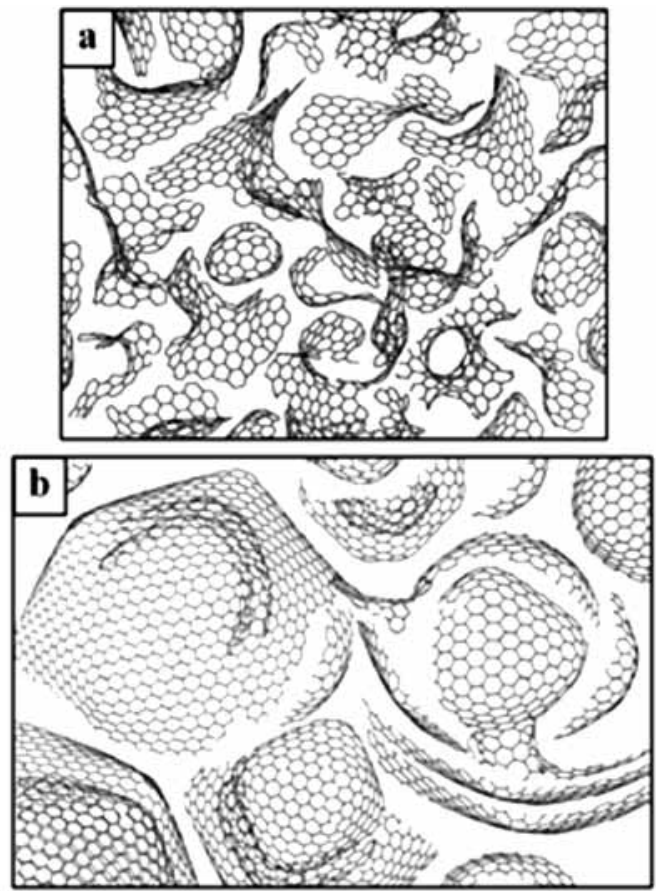

Figura 17: Modelos de Harris para (a) a estrutura do carbono não grafitizável comum e (b) para a estrutura do carbono vítreo obtido pelo tratamento a altas temperaturas [9].

[Figure 17: Harris' models for (a) the structure of common nongraphitizing carbon and for $(b)$ the structure of high temperature glassy carbon [9].]

Interferência de agentes externos no carbono produzido pelo termofixo

Como já comentado na seção Características $e$ propriedades da resina para o processamento do refratário, 
o processo de cura das resinas termofixas pode ser significativamente afetado pelos demais componentes do refratário, como no caso da aceleração da cura das resinas fenólicas devido à presença de óxidos básicos. Por outro lado, nas características e propriedades do carbono não grafitizável obtido com a pirólise do termofixo, a influência dos óxidos refratários, dos "flakes" de grafite e de outros constituintes usuais dos refratários aparenta ser sempre mínima. Yamaguchi et al [39] puderam averiguar esse comportamento nos casos dos óxidos $\mathrm{Al}_{2} \mathrm{O}_{3}, \mathrm{TiO}_{2}, \mathrm{ZrO}_{2}$, $\mathrm{MgO}$ e $\mathrm{SiO}_{2}$, os quais foram combinados em diversas proporções com o grafite puro e com o carbono obtido da pirólise de uma resina fenólica, sendo essas misturas estudadas quanto à sua resistência à oxidação pela técnica de análise térmica diferencial (DTA, "Differential Thermal Analysis"). No caso do grafite, a combinação com os óxidos $\mathrm{SiO}_{2}, \mathrm{MgO}, \mathrm{ZrO}_{2}$ e $\mathrm{TiO}_{2}$ proporcionou ganhos expressivos para a sua resistência à oxidação, elevando a temperatura do pico exotérmico dessa reação em algumas dezenas de graus. $\mathrm{O}$ efeito desses óxidos pode ser explicado pela capacidade comum a todos eles de doar elétrons à estrutura do grafite, o que a estabiliza e assim dificulta o ataque do oxigênio. Inclusive, devido ao aumento gradativo dessa capacidade quando se passa do $\mathrm{SiO}_{2}$, para o $\mathrm{MgO}$, para o $\mathrm{ZrO}_{2}$ e para o $\mathrm{TiO}_{2}$, os incrementos na temperatura do pico exotérmico também aumentaram nessa mesma ordem dos óxidos. Quanto ao efeito do $\mathrm{Al}_{2} \mathrm{O}_{3}$, por sua tendência de roubar elétrons, esse óxido acabou tornando o grafite mais instável $\mathrm{e}$, conseqüentemente, mais sujeito à reação com o oxigênio, causando a redução da temperatura do pico de oxidação. Já no caso do carbono não grafitizável derivado do termofixo, não se verificou qualquer alteração da sua resistência à oxidação devido à presença dos óxidos refratários, mesmo quando esses foram misturados a ele na proporção de $50 \%$ em peso. Tal diferença tão expressiva entre os dois tipos de carbono é explicada pelos autores como uma conseqüência do grande número de defeitos e das ligações carbono-carbono mais fracas que formam o carbono não grafitizável, características que, por facilitarem muito as reações de oxidação, tornariam a influência dos óxidos pouco significativa, a ponto desta não transparecer nos resultados de DTA.

Quanto ao efeito das partículas de grafite, de acordo com Rand e McEnaney [8], a presença delas em meio ao termofixo poderia levá-lo a desenvolver alguma grafitização na medida em que ele se contraísse ao redor dessas partículas ao longo da sua pirólise. No entanto, esse chamado processo de grafitização sob tensão parece ter seu alcance muito limitado à vizinhança da partícula do "filler" incompressível (que, nesse caso, seria a partícula de grafite). Da mesma forma, a aplicação de alguma pressão externa durante a pirólise também poderia favorecer e acelerar a formação de regiões cristalizadas em meio ao carbono não grafítico, mas esse efeito seria igualmente limitado a pequenas espessuras. Rand e McEnaney também fazem referência à investigação de R. Lum et al sobre o efeito do negro de fumo na pirólise de termofixos, os quais chegaram à conclusão de que essas partículas de carbono têm a capacidade de reduzir significativamente a produção de voláteis na pirólise de resinas novolacas, mesmo que essas não estejam curadas. Tal comportamento foi atribuído à interação dos voláteis com a superfície das partículas de negro de fumo, o que Rand e McEnaney destacam por mostrar a possibilidade de fazer uso da química de superfícies para aumentar a fixação de carbono. Portanto, verifica-se por essas informações a dificuldade para se interferir na pirólise dos polímeros termofixos no intuito de efetivamente modificar as características do carbono que será formado, isso a ponto de que as propriedades do refratário que o contenha sejam afetadas. Talvez agora, à luz das novas teorias sobre a estrutura do carbono não grafitizável expostas anteriormente, a dimensão dessa dificuldade comece a ser mais bem compreendida.

$\mathrm{Na}$ literatura atual, é possível identificar uma grande diversidade de técnicas que procuram de alguma forma modificar a estrutura do carbono não grafítico. Contudo, a maioria delas já se mostra inviável para a aplicação no campo dos refratários por serem adequadas apenas a corpos de pequeno volume, por atuarem apenas em superfícies, por necessitarem de resinas específicas ou mesmo pelos próprios custos que envolveriam. Entre todas as possibilidades averiguadas, apenas as chamadas técnicas de grafitização catalítica apresentaram aspectos atrativos para a aplicação em refratários resinados, principalmente pela praticidade de seus métodos. Na verdade, a eficácia da grafitização catalítica para a aplicação em refratários já teria sido comprovada, isso de acordo com os resultados que estão apresentados na patente desenvolvida em 2001 pelos pesquisadores Bartha et al [40], da empresa de refratários alemã Refratechnik. Na próxima seção, essa patente e outros trabalhos sobre a grafitização catalítica são apresentados e discutidos.

\section{Grafitização catalítica}

De uma forma geral, as técnicas de grafitização catalítica consistem simplesmente em acrescentar ao carbono não grafítico, ou mesmo diretamente a sua fonte (como as resinas termofixas), aditivos que são capazes de catalisar a grafitização do carbono durante um tratamento térmico realizado a temperaturas suficientemente elevadas. Esses aditivos envolvem principalmente metais e compostos metálicos, com destaque para os metais do grupo de transição. O fenômeno da grafitização catalítica é conhecido desde o início do século XX, e aparenta ter sido alvo de estudos intensos entre as décadas de 70 e 90 . Nesse período, destacam-se os trabalhos do grupo de pesquisa ligados aos pesquisadores Asao Oya e Sugio Otani, que se dedicaram a analisar uma grande diversidade de aditivos para compreender esse fenômeno. É possível obter uma visão geral do trabalho desses pesquisadores por meio de um de seus artigos publicado em 1978 [41], no qual se analisa a ação catalítica dos vinte e dois metais que estão destacados na Fig. 18. Como fontes de carbono, foram usadas uma resina fenol-formaldeído (PF) do tipo resol, considerada uma fonte não grafitizável, e uma resina 3,5-dimetilfenol-formaldeído 


\begin{tabular}{|c|c|c|c|c|c|c|c|c|c|c|c|c|c|}
\hline \multirow{2}{*}{$\frac{\mathrm{IIA}}{\mathrm{Be}}$} & \multirow{5}{*}{\multicolumn{5}{|c|}{$\begin{array}{l}\text { Fases obtidas } \\
\text { G: fase gra fítica } \\
\text { GT: fase gra fítica e turbostrática } \\
\text { A: gra fitização homogênea } \\
\text {-: sem efeito catalisador }\end{array}$}} & \multicolumn{5}{|c|}{ Mecanismo de catálise } & \multirow{4}{*}{$\begin{array}{c}\text { IIIA } \\
\mathrm{B} \\
\mathrm{A} \\
\mathrm{A}\end{array}$} & \multirow{2}{*}{$\begin{array}{c}\text { IVA } \\
\mathrm{C} \\
\end{array}$} & \multirow{2}{*}{$\frac{\text { VA }}{\mathrm{N}}$} \\
\hline & & & & & & \multirow{4}{*}{\begin{tabular}{|l} 
\\
\end{tabular}} & \multirow{3}{*}{\multicolumn{4}{|c|}{$\begin{array}{l}\text { formação-decomposição } \\
\text { dissolução-precipitação } \\
\text { grafitização homogênea }\end{array}$}} & & & \\
\hline & & & & & & & & & & & & & \\
\hline & & & & & & & & & & & & & \\
\hline$\overline{\mathrm{Mg}}$ & & & & & & & \multicolumn{4}{|c|}{ desconhecido } & $\overline{\mathrm{Al}}$ & $\mathrm{Si}$ & $P$ \\
\hline G & IIIB & IVB & VB & VIB & VIIB & \multicolumn{3}{|c|}{$1-$ VIIIB- } & IB & IIB & GT & G & \\
\hline$\overline{\mathrm{Ca}}$ & Sc & $\mathrm{Ti}$ & $\overline{\mathrm{V}}$ & $\mathrm{Cr}$ & $\mathrm{Mn}$ & $\mathrm{Fe}$ & $\overline{\mathrm{Co}}$ & $\mathrm{Ni}$ & $\overline{\mathrm{Cu}}$ & $\overline{\mathrm{Zn}}$ & $\mathrm{Ga}$ & $\overline{\mathrm{Ge}}$ & As \\
\hline $\begin{array}{l}\mathrm{G} \\
\mathrm{G}\end{array}$ & & $\begin{array}{c}\text { G } \\
\text { GT }\end{array}$ & $\begin{array}{c}\text { G } \\
\text { GT }\end{array}$ & $\begin{array}{c}\mathrm{G} \\
\mathrm{GT}\end{array}$ & $\begin{array}{c}\mathrm{G} \\
\mathrm{GT}\end{array}$ & $\begin{array}{c}\text { G } \\
\text { GT }\end{array}$ & $\begin{array}{c}\text { G } \\
\text { GT }\end{array}$ & $\begin{array}{c}\text { G } \\
\text { GT }\end{array}$ & $\overline{\mathrm{G}}$ & - & & $\overline{\text { G }}$ & \\
\hline $\mathrm{Sr}$ & $\mathrm{Y}$ & $\overline{\mathrm{Zr}}$ & $\overline{\mathrm{Ni}}$ & Mo & Tc & $\overline{\mathrm{Ru}}$ & $\mathrm{Rh}$ & $\mathrm{Pd}$ & $\mathrm{Ag}$ & $\overline{\mathrm{Cd}}$ & In & $\mathrm{Sn}$ & $\mathrm{Sb}$ \\
\hline & & & & $\begin{array}{c}\text { G } \\
\text { GT }\end{array}$ & & & & & & - & & - & - \\
\hline $\mathrm{Ba}$ & $\mathrm{La}$ & Hf & $\mathrm{Ta}$ & $\mathrm{W}$ & $\operatorname{Re}$ & Os & $\mathrm{Ir}$ & Pt & $\mathrm{Au}$ & $\overline{\mathrm{Hg}}$ & $\mathrm{Tl}$ & $\overline{\mathrm{Pb}}$ & $\overline{\mathrm{Bi}}$ \\
\hline & & & & $\begin{array}{c}\mathbf{G} \\
\mathrm{GT}\end{array}$ & & & & & & & & - & - \\
\hline
\end{tabular}

Figura 18: Em destaque, os metais avaliados e seus resultados quanto ao efeito catalisador e aos mecanismos de catálise. Os resultados para a resina 3,5-DMPF estão na linha superior de cada célula e para a resina PF na linha inferior (adaptado de [41]). [Figure 18: Evaluated metals (highlighted) and their results considering their catalytic effect and respective catalysis mechanism. The 3.5-DMPF resin results are at the top line of each cell, and the PF resin ones are at the bottom line (adapted from [41]).]

(3,5-DMPF), considerada uma fonte grafitizável. Os pós metálicos usados apresentavam, em sua maioria, uma granulometria entre 50 e 100 mesh $(0,15$ a $0,30 \mathrm{~mm})$, e sua adição às duas resinas foi realizada de formas distintas. Para a resina $\mathrm{PF}$, os pós puderam ser misturados diretamente a ela, sendo feita em seguida a cura das amostras a $100^{\circ} \mathrm{C}$ e a pirólise a $800^{\circ} \mathrm{C}$ (sob atmosfera inerte). A adição dos metais foi controlada de forma que os seus teores nas amostras pirolisadas ficassem sempre em $10 \%$ p. Já a resina 3,5DMPF, sem que passasse antes por um processo de cura, foi diretamente submetida à pirólise a $800^{\circ} \mathrm{C}$ e em atmosfera inerte. $\mathrm{O}$ carbono produzido foi então moído e misturado a $20 \%$ em peso de cada pó metálico. De acordo com os comentários feitos na seção Efeito da estrutura molecular da resina fenólica sobre as propriedades do carbono deste artigo, acredita-se que esse procedimento foi adotado devido à alta viscosidade característica dessa resina (que não permitiria que os pós fossem adequadamente dispersos nela) e porque a realização da cura prejudicaria a sua capacidade de grafitização.

Assim, considerando as amostras de referência isentas de qualquer aditivo, as 23 amostras de cada resina foram submetidas a um tratamento térmico de uma hora a 2600 ${ }^{\circ} \mathrm{C}$, em atmosfera inerte, para a ocorrência dos possíveis processos de catálise da grafitização. Na tentativa de se identificar os mecanismos de catálise desses metais, outras amostras foram confeccionadas e tratadas a temperaturas intermediárias entre 1000 e $3000{ }^{\circ} \mathrm{C}$. Na análise desses materiais foram empregadas as técnicas de difração de raios $\mathrm{X}$ e microscopia óptica.

Considerando as amostras nas quais se constatou a atuação dos metais como catalisadores, foi possível classificá-las em três grupos de acordo com o resultado da catálise: amostras em que houve a formação da fase grafítica $(\mathrm{G})$; amostras em que foram formadas tanto a fase grafítica como a turbostrática (GT); e amostras em que houve a aceleração do processo de desenvolvimento da estrutura carbonácea já próprio da fonte de carbono (A). Essa classificação é apresentada na Fig. 18, na qual também estão sinalizados os casos em que o metal não atuou como catalisador. Quanto à fase turbostrática, essa pode ser definida como uma estrutura com um grau de organização cristalina intermediário entre o carbono não grafítico e o grafítico. Pela Fig. 18, pode-se verificar que ocorreram alguns casos de metais que agiram como catalisadores para o carbono da resina PF, mas não para o da resina 3,5-DMPF. Esse comportamento provavelmente é uma conseqüência da carbonização da resina 3,5-DMPF ter sido realizada antes da adição dos catalisadores, e também pelo fato de que, sendo do tipo grafitizável, o carbono produzido por essa resina seria menos reativo para com os metais quando comparado ao da resina PF. Além da classificação pelo resultado da catálise, os metais que também puderam ser parcialmente distinguidos quanto ao seu modo de atuação, isso de acordo com os três mecanismos de catálise que são usados pelos autores para explicar a grafitização catalítica. Os metais que teriam facilidade para produzir carbetos (ou seja, que apresentassem valores negativos de entalpia e de energia livre para a reação de formação de carbetos) tenderiam a agir pelo mecanismo denominado formaçãodecomposição, que seria constituído por ciclos em que o metal primeiro reage com o carbono, produzindo um carbeto, o qual logo depois se decompõe se a temperatura for propícia. Assim, o carbono é liberado da estrutura não grafítica rígida e ganha liberdade para formar uma estrutura mais organizada ( $\mathrm{G}$ ou $\mathrm{T}$ ) com a decomposição do carbeto, enquanto o metal retorna ao início do ciclo. Os metais que atuam por esse mecanismo pertencem predominantemente 
aos grupos IVB a VIIB da tabela periódica que, devido as suas camadas eletrônicas "d" parcialmente preenchidas ( 2 a 5 elétrons), tenderiam a formar ligações fortes com o carbono. O cálcio, o alumínio e o silício também formam carbetos com facilidade e, embora o mecanismo de catálise do magnésio não tenha sido deixado claro pelos autores, é possível que ele também atue por meio da formação de carbetos. Já os metais do grupo VIIIB, por terem suas camadas "d" quase completas (6 a 8 elétrons), são mais propícios a dissolver o carbono (que seria dissolvido como um cátion), gerando o mecanismo de catálise denominado dissolução-precipitação. Nesse mecanismo, ocorreria a contínua dissolução do carbono da estrutura não grafítica na partícula de metal, ao mesmo tempo em que o carbono já dissolvido estaria sendo precipitado com uma estrutura mais organizada ( $\mathrm{G}$ ou T). Além dos metais do grupo VIIIB, o germânio e o cobre também atuariam por esse método. O terceiro mecanismo de catálise é designado como sendo a aceleração da grafitização homogênea, no qual o catalisador auxiliaria na formação de fases grafíticas e turbostráticas somente se a fonte de carbono em questão já fosse apta para formá-las na ausência de quaisquer aditivos. De acordo com a Fig. 18, o boro foi o único metal a atuar por esse mecanismo, tendo-se verificado que ele realmente acelerou a grafitização do carbono da resina 3,5-DMPF, enquanto o carbono da resina $\mathrm{PF}$ atingiu apenas uma estrutura um pouco mais ordenada em comparação à amostra isenta de aditivos e tratada na mesma temperatura. Em ambos os casos, esse fenômeno foi constatado pelo aumento da intensidade e pelo estreitamento dos picos de difração de raios $\mathrm{X}$ referentes ao carbono lamelar. Para as condições experimentais utilizadas pelos autores em [41], o boro foi o único metal a desenvolver esse mecanismo em razão da capacidade do carbono de dissolvê-lo como um soluto instersticial ou substitucional (o que, inclusive, causa o deslocamento dos picos de difração característicos da estrutura lamelar do carbono). No entanto, a grafitização homogênea também é possível quando são usados catalisadores finamente divididos, como metais vaporizados [42]. Caso o boro metálico seja adicionado em teores superiores ao seu limite de solubilidade no carbono (que aparenta estar em torno de $1 \%$ p), a fração do metal que não for dissolvida poderá formar o carbeto de boro a temperaturas acima de $1400{ }^{\circ} \mathrm{C}$ [43]. A partir de $2200{ }^{\circ} \mathrm{C}$, esse carbeto passaria a atuar como catalisador pelo mecanismo de dissoluçãoprecipitação (pois já estaria próximo do seu ponto de fusão, a $2350{ }^{\circ} \mathrm{C}$ ), possibilitando o desenvolvimento das fases $\mathrm{T}$ e $\mathrm{G}$ no carbono da resina $\mathrm{PF}$, como comprovam os difratogramas da Fig. 19.

Estudo realizado por Zhang e Yamaguchi [44] concluiu que a eficácia do $\mathrm{B}_{4} \mathrm{C}$ como aditivo antioxidante também seria uma conseqüência da sua capacidade de promover a grafitização do carbono, o que se somaria, portanto, aos seus outros mecanismos contra a oxidação citados na seção Aditivos aplicados às resinas na produção de refratários: agentes antioxidantes. Essa capacidade é verificada pelos difratogramas apresentados na Fig. 20,

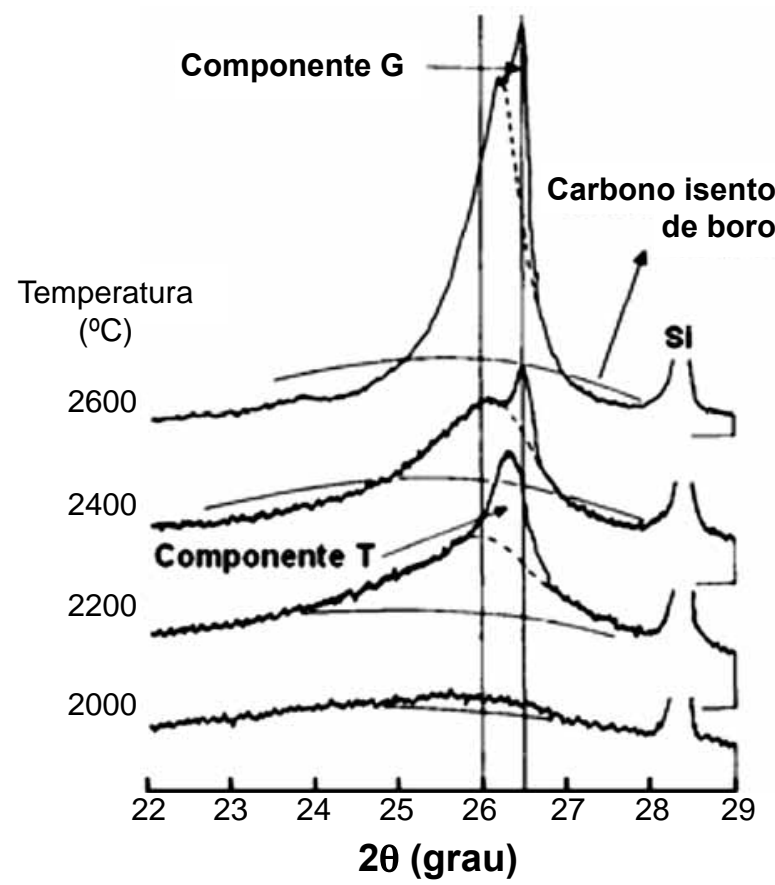

Figura 19: Difratogramas de raios $\mathrm{X}$ para as amostras de carbono da resina $\mathrm{PF}$, tratadas de 2000 a $2600{ }^{\circ} \mathrm{C}$, isentas e com a adição de $5 \%$ p de boro metálico (adaptado de [43]).

[Figure 19: X-ray diffraction patterns for PF resin carbon samples, treated from 2000 to $2600{ }^{\circ} \mathrm{C}$, free and with the addition of $5 \% \mathrm{w}$ of metallic boron (adapted from [43]).]

que foram obtidos de amostras de carbono de uma resina fenólica, as quais foram aditivadas ou não com $\mathrm{B}_{4} \mathrm{C}$ em pó (com tamanho de partícula inferior a $10 \mu \mathrm{m}$ ). Na Fig. $20 \mathrm{a}$, referente às amostras isentas do aditivo, os picos de difração relacionados à família de planos 002 e 101 da estrutura grafítica permanecem pouco definidos mesmo com o tratamento a $1650{ }^{\circ} \mathrm{C}$. Com a adição de $5 \%$ de $\mathrm{B}_{4} \mathrm{C}$, como se verifica na Fig. 20b, esses picos já começam a se destacar a partir das amostras tratadas a $1000{ }^{\circ} \mathrm{C}$, especialmente o pico relativo à família de planos 002 , que atinge uma intensidade expressiva a $1650{ }^{\circ} \mathrm{C}$. Logo se observa que $\mathrm{o}$ efeito catalisador do $\mathrm{B}_{4} \mathrm{C}$ ocorreu a temperaturas muito inferiores às constatadas nos trabalhos de Oya e Otani. Além disso, embora utilizem o carbeto, Zhang e Yamaguchi [44] explicam a ação catalisadora do $\mathrm{B}_{4} \mathrm{C}$ não pelo mecanismo de dissoluçãoprecipitação de Oya e Otani, mas pela capacidade do boro de entrar em solução sólida na estrutura do carbono. Dentro da estrutura, o boro atuaria como um nucleante para o crescimento dos cristais de grafite. A teoria adotada por Zhang e Yamaguchi é apoiada pelo comportamento do grau de cristalinidade e da resistência à oxidação do carbono em função do teor de $\mathrm{B}_{4} \mathrm{C}$, visto que esses fatores passaram a não mais evoluir depois que a adição de $\mathrm{B}_{4} \mathrm{C}$ ultrapassou o seu limite de solubilidade na matriz de carbono (que seria de $0,75 \%$ p, para o tratamento térmico a $1500{ }^{\circ} \mathrm{C}$ ).

Portanto, verifica-se que os resultados e explicações para o comportamento do boro como catalisador da 

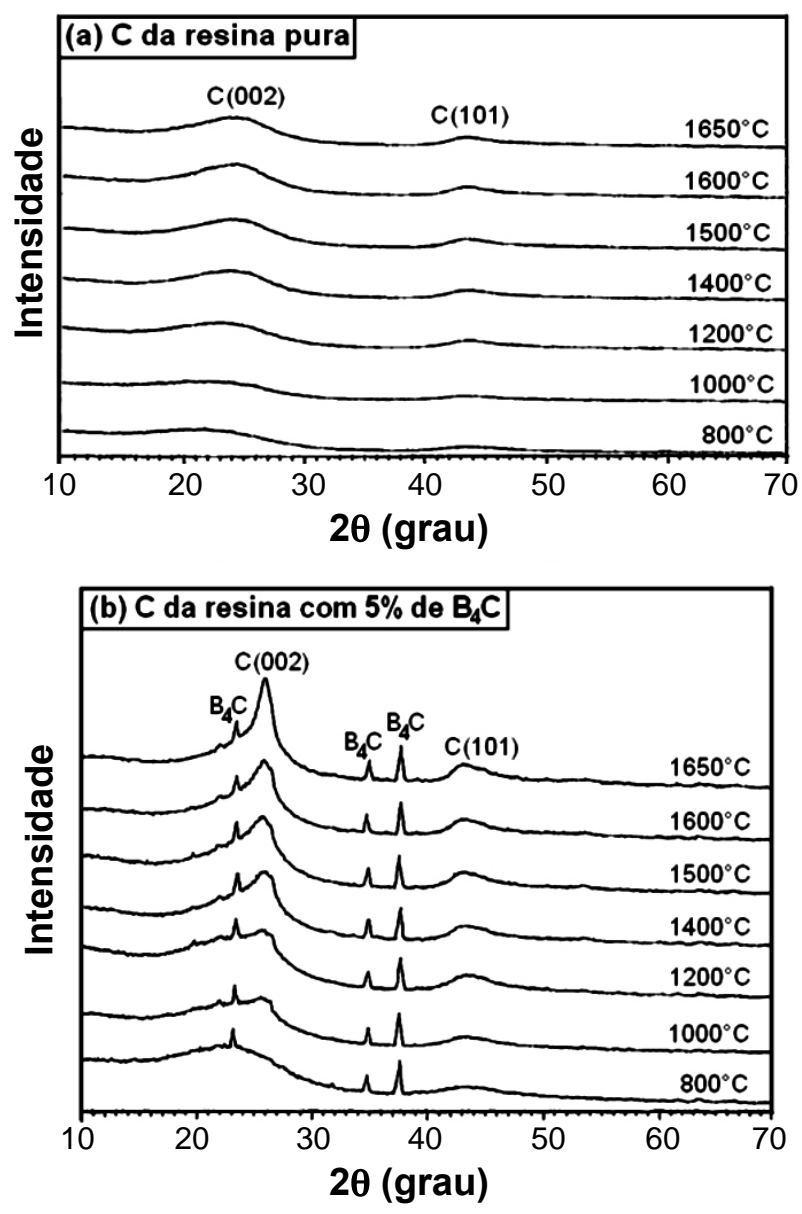

Figura 20: Difratogramas de raios $\mathrm{X}$ para as amostras de carbono de resina fenólica, tratadas de 800 a $1650{ }^{\circ} \mathrm{C}$, isentas de $\mathrm{B}_{4} \mathrm{C}$ (a) e aditivadas com 5\%p de $\mathrm{B}_{4} \mathrm{C}$ (b) (adaptado de [44]).

[Figure 20: $X$-ray diffraction patterns for phenolic resin carbon samples, treated from 800 to $1650{ }^{\circ} \mathrm{C}$, (a) free of $\mathrm{B}_{4} \mathrm{C}$ and $(b)$ with the addition of $5 \% \mathrm{w}$ of $\mathrm{B}_{4} \mathrm{C}$ (adapted from [44]).]

grafitização diferem significativamente entre os trabalhos desses pesquisadores. Cogita-se que essas diferenças seriam conseqüentes do fato de Oya e Otani terem utilizado o boro metálico ao invés do carbeto, e/ou também do uso de pós com granulometrias distintas. Além de metais, os trabalhos de Oya e Otani também propõem o uso de alguns compostos metálicos inorgânicos e compostos organometálicos como agentes catalisadores. Tais opções certamente poderiam ser muito vantajosas em vista do problema da alta reatividade dos metais pulverizados, a qual favorece a ocorrência de reações indesejáveis antes que esses possam atuar como catalisadores da grafitização. Entre esses compostos metálicos inorgânicos estão incluídos carbetos, nitretos, óxidos, carbonatos, cloretos, hidróxidos, entre outros, mas apenas de alguns metais específicos. $\mathrm{O}$ óxido de boro $\left(\mathrm{B}_{2} \mathrm{O}_{3}\right)$, por exemplo, ao contrário do carbeto e do boro metálico, não tem qualquer atuação como catalisador, enquanto os óxidos de ferro e cério já apresentam alguma atividade [42]. A forma de atuação dos compostos inorgânicos pode ser bem diversa. Alguns apenas se decompõem para então produzir as partículas metálicas "in-situ" (como no caso do óxido, do fluoreto e do cloreto de cobre). Outros já fazem parte do próprio mecanismo de catálise do metal, como os carbetos formados no processo de formação-decomposição, e também há aqueles que seriam efetivamente os próprios catalisadores, como nos casos do carbonato e do hidróxido de cálcio, os quais formariam complexos com o carbono [42]. Segundo Oya e Marsh [42], os compostos organometálicos seriam aplicados principalmente para obter uma distribuição fina do metal pelo carbono, uma vez que essas substâncias se decomporiam a altas temperaturas, produzindo as partículas metálicas "in-situ". Oya et al [45], por exemplo, utilizaram um composto organometálico de níquel (acetilacetonato de níquel II) para chegar a uma dispersão mais fina desse metal pela resina fenólica. Considerando a quantidade de níquel proveniente da degradação do composto organometálico, e a massa obtida com a pirólise preliminar das amostras de resina a $800{ }^{\circ} \mathrm{C}$, as mesmas foram preparadas com teores de níquel de 1 e $30 \%$ p. Porém, ao invés de $2600{ }^{\circ} \mathrm{C}$, agora as temperaturas de tratamento térmico para essas amostras não ultrapassaram os $1800{ }^{\circ} \mathrm{C}$, sendo que os autores inclusive comentaram que, a essa temperatura, o níquel já teria sido completamente removido pelos processos de difusão. Como se observa pelos difratogramas de raios $\mathrm{X}$ apresentados na Fig. 21, temperaturas abaixo de $1800{ }^{\circ} \mathrm{C}$ realmente já se mostraram suficientes para que o níquel começasse a agir como catalisador da grafitização.

\section{a 1\%p niquel}

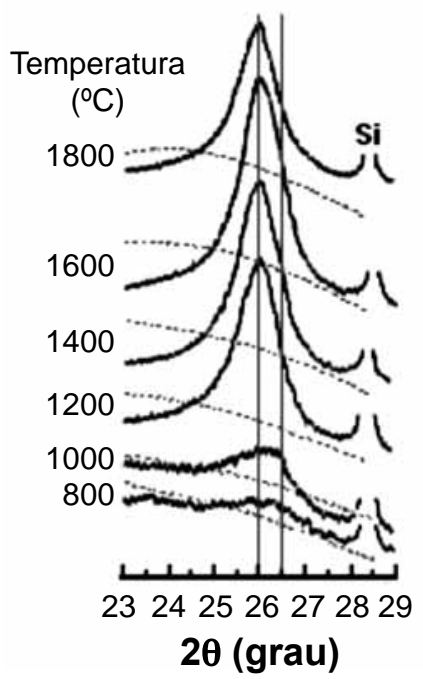

回 30\%p niquel

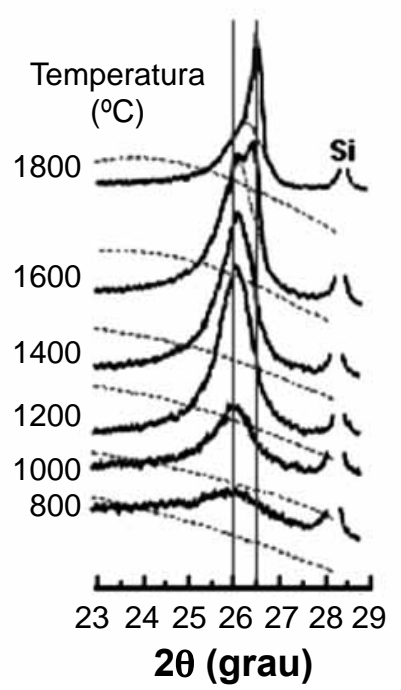

Figura 21: Difratogramas de raios $\mathrm{X}$ para amostras de carbono com (a) $1 \% \mathrm{p}$ e (b) $30 \% \mathrm{p}$ de níquel, tratadas de 800 a $1800^{\circ} \mathrm{C}$. As linhas pontilhadas representam amostras isentas de níquel [45].

[Figure 21: X-ray diffraction patterns for carbon samples with (a) $1 \% \mathrm{w}$ and (b) $30 \% \mathrm{w}$ of nickel, treated from 800 to $1800{ }^{\circ} \mathrm{C}$. The dotted lines represent the nickel free samples [45].]

Mesmo adicionado no teor de $1 \%$ p, esse metal já demonstra resultados expressivos de acordo com a Fig. 21a. De fato, pelos trabalhos de Oya e Otani que puderam ser consultados, o níquel foi o catalisador que atuou nas 
temperaturas mais baixas, possível razão para que tenha sido o metal mais estudado por esses pesquisadores. Oya e Otani [45] também levantaram uma série de observações que apontam como os mecanismos de grafitização elaborados até aquele momento (grafitização homogênea, dissoluçãoprecipitação ou formação-decomposição) ainda não seriam suficientes para explicar alguns comportamentos e características da microestrutura do carbono submetido à catálise. Uma dessas características, por exemplo, seria a memória estrutural que a fase turbostrática acaba retendo em relação ao carbono não grafítico que lhe deu origem, algo que, teoricamente, não poderia ser permitido pelos mecanismos de dissolução-precipitação ou formaçãodecomposição. A alta resistência térmica apresentada pela fase turbostrática seria outro comportamento inexplicável, visto que se esperaria que o processo de organização desta fase avançasse com o aumento da temperatura a ponto de grafitizá-la por completo. Porém, isso não aparenta ocorrer mesmo a mais de $2700{ }^{\circ} \mathrm{C}[46,47]$. É interessante analisar todas essas dificuldades apontadas para a efetiva grafitização do carbono não grafítico sob o ponto de vista da nova estrutura que está sendo proposta para o mesmo, como foi apresentado no capitulo 3. Sendo realmente os anéis pentagonais e heptagonais os responsáveis pela configuração da estrutura não grafítica, e sendo esses anéis tão estáveis à temperatura (e talvez mesmo a processos químicos), nisso poderia estar a explicação tanto para a memória estrutural como para a resistência à temperatura da estrutura turbostrática. Contudo, independentemente da compreensão que se alcance sobre os mecanismos de grafitização catalítica propostos por Oya e Otani, o fato é que nenhum deles demonstra ser viável ou mesmo capaz de proporcionar benefícios expressivos para os refratários contendo carbono. Com exceção do níquel, todos os catalisadores analisados por esses autores começaram a apresentar resultados significantes apenas quando adicionados em teores elevados e após a realização de tratamentos a temperaturas acima de $2200{ }^{\circ} \mathrm{C}$, o que já está acima do intervalo comum aos processos siderúrgicos. Além disso, tanto no mecanismo de formação-decomposição como no de dissolução-precipitação, o desenvolvimento das fases grafítica e turbostrática ocorrerá somente em uma região limitada ao redor das partículas do catalisador. Mesmo com a difusão dessas partículas, a microestrutura final do carbono acaba permanecendo heterogênea, como exemplifica a Fig. 22.

Assim, ficando a fase grafítica "ilhada" por uma matriz não grafítica, o ganho na cristalização acusado pela difração de raios $\mathrm{X}$ não se reflete em ganhos para as propriedades térmicas, elétricas, mecânicas e químicas da amostra de carbono como um todo, sendo até mesmo possível que essas propriedades sejam prejudicadas pela formação dessa microestrutura heterogênea [42]. Nesse ponto, o mecanismo de grafitização homogênea aparentaria ser vantajoso, pois, como seu próprio nome sugere, ele atua de maneira uniforme por todo o volume do carbono não grafítico. Por outro lado, de acordo com a teoria formulada por Oya e Otani, esse mecanismo pouco beneficiaria as propriedades

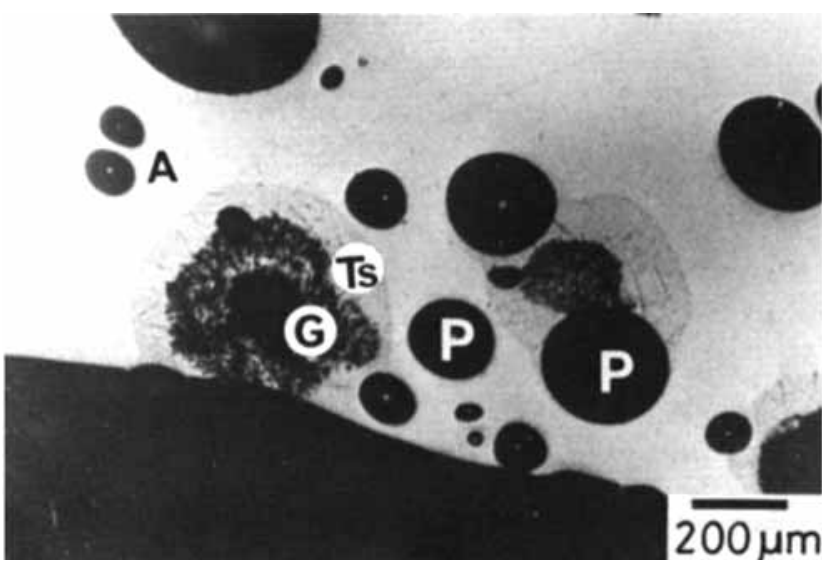

Figura 22: Microestrutura do carbono da resina fenólica aditivado com partículas de níquel $(100 \mu \mathrm{m}) . \mathrm{G}=$ fase grafítica, $\mathrm{Ts}=$ fase turbostrática, $\mathrm{A}=$ carbono não grafítico original, $\mathrm{P}=$ poro [46].

[Figure 22: Structure of a phenolic resin carbon additivated with $100 \mu \mathrm{m}$ nickel powder. $G=$ graphitic phase, $T s=$ turbostratic phase, $A=$ original non-graphitic carbon, $P=$ pore [46].]

do carbono derivado de fontes não grafitizáveis, tais como as resinas fenol-formaldeído convencionais, principalmente em temperaturas inferiores a $2000{ }^{\circ} \mathrm{C}$. Assim, verificase que as técnicas de grafitzação catalítica, apesar de sua grande diversidade e de serem realmente capazes de causar alterações microestruturais, ainda acabaram ficando muito restritas quanto aos seus efetivos impactos sobre as propriedades do carbono não grafítico. Isso talvez explique a aparente redução do interesse por esse tema nos últimos vinte anos. Mesmo assim, os pesquisadores Bartha, Jansen e Daldrup, por meio de uma patente publicada em 2001 [40], retomaram essas técnicas para aplicá-las justamente à produção de refratários contendo carbono, tendo como foco principal os refratários de $\mathrm{MgO}-\mathrm{C}$. Entretanto, nessa patente e em dois artigos de Jansen [48, 49], eles demonstram estar alcançando resultados muito superiores aos de Oya e Otani.

Os aditivos catalisadores sugeridos por Bartha et al [40] incluiriam compostos organometálicos facilmente redutíveis, como metalocenos, benzoatos, octoatos e naftenatos, além de sais metálicos solúveis na resina termofixa e óxidos metálicos quimicamente precipitados ou micronizados. Todos esses compostos seriam baseados em metais de transição, havendo preferência pelo cobre, o cromo, o ferro, o níquel e o cobalto. Os autores afirmam e demonstram que esses agentes, adicionados às resinas termofixas em teores de 0,1 a $10 \%$ p (sendo $1 \%$ p o valor típico), seriam capazes de causar a grafitização do seu carbono a temperaturas inferiores a $1000{ }^{\circ} \mathrm{C}$. Ou seja, em uma temperatura totalmente satisfatória para a produção de refratários, e que faria as resinas suplantarem até mesmo a vantagem da capacidade de grafitização do piche (visto que o carbono produzido pelo piche estaria apenas no princípio do processo de cristalização a $1000{ }^{\circ} \mathrm{C}$, como pode ser verificado em [49]). Os difratogramas apresentados na Fig. 23, extraídos de um artigo de Jansen [48], vêm a comprovar o alto grau de cristalinidade atingido entre 900 a $1500{ }^{\circ} \mathrm{C}$ pelo carbono produzido por uma resina aditivada com um agente 
grafitizante quando comparado ao carbono derivado de uma resina isenta dessas substâncias. Já a Fig. 24 compara as micrografias desses dois materiais, sendo que a Fig. 24b dá a entender que a grafitização teria ocorrido uniformemente pela matriz de carbono, formando uma fase contínua (embora não seja possível comparar essa micrografia com a da Fig. 22 devido à diferença nas escalas).
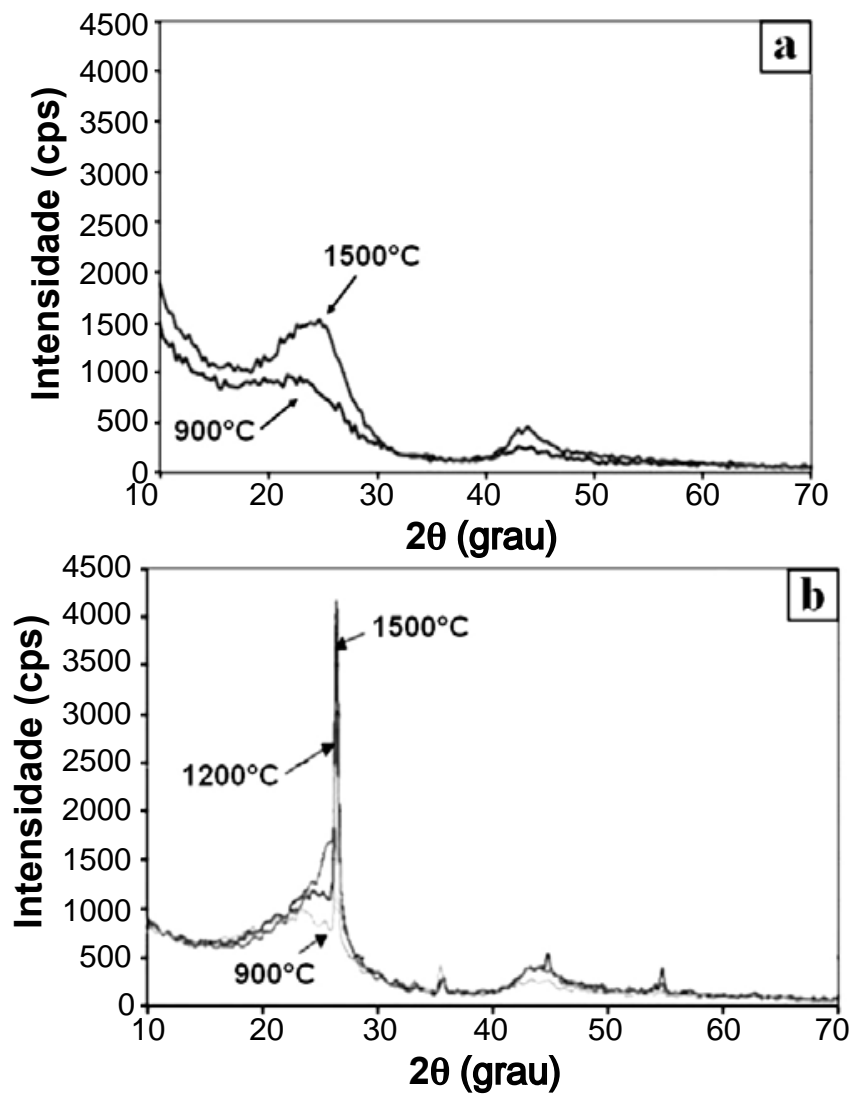

Figura 23: Difratogramas de raios X de amostras de carbono tratadas em diversas temperaturas e derivadas de (a) uma resina fenólica comum e (b) uma resina com agentes grafitizantes (adaptado de [48]). [Figure 23: X-ray diffraction patterns of carbon samples treated at different temperatures and obtained from (a) a conventional phenolic resin and (b) a resin with graphitizing agents (adapted from [48]).]

Bartha et al [40] destacam que um fator crucial para que esses aditivos causem o efeito desejado é que eles estejam disponíveis como moléculas individualizadas logo no início do processo de carbonização do termofixo, entre 400 a $500{ }^{\circ} \mathrm{C}$. Para atingir tal dispersão, é valido adicionálos diretamente como pós micronizados, como suspensões, ou mesmo dissolvidos em um solvente. Como exemplo disso, pode-se citar o procedimento experimental aplicado a uma das composições refratárias descritas pela patente. Neste procedimento, primeiro é feita uma mistura entre um sinter de $\mathrm{MgO}$ e o agente grafitizante (o organometálico ferroceno), na proporção de 50:1, a qual então é moída até que $o$ aditivo alcance um tamanho de partícula entre 1 e 10 $\mu \mathrm{m}$. Esse preparado é em seguida acrescentado a seco ao restante da composição refratária sob mistura. Também por meio desses exemplos, compreendeu-se que a cura da resina
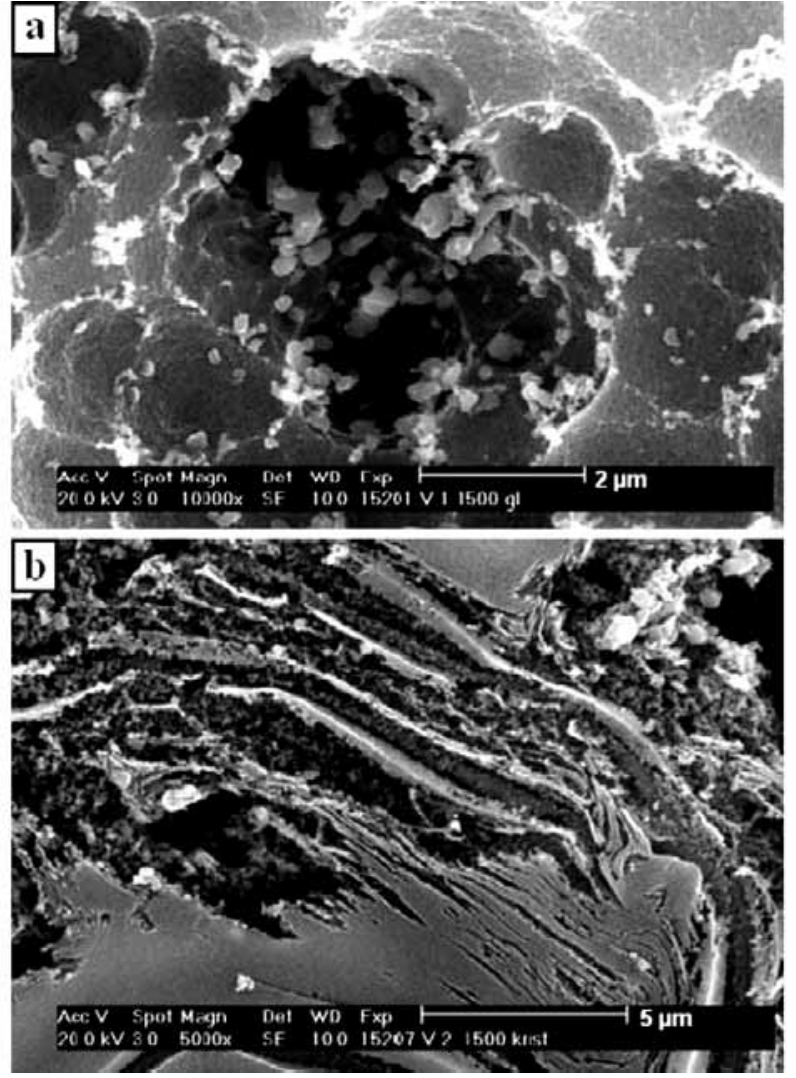

Figura 24: Micrografias de amostras de carbono tratadas a $1500{ }^{\circ} \mathrm{C}$, provenientes de (a) uma resina fenólica comum e (b) de uma resina aditivada com agentes grafitizantes (adaptado de [48]).

[Figure 24: Micrographs from carbon samples treated at $1500{ }^{\circ} \mathrm{C}$, obtained from (a) a conventional resin and $(b)$ a resin additived with graphitizing agents (adapted from [48]).]

pode ser realizada normalmente antes da etapa de queima do refratário. Isso apenas não ficou completamente claro devido aos autores usarem o termo "secagem" ao invés do termo "cura". Resultados apresentados pela patente e pelos artigos de Jansen mostram que a grafitização catalítica teria proporcionado benefícios significativos, principalmente à resistência à oxidação, à resistência mecânica a frio e a quente, e à resistência ao choque térmico do refratário. Entretanto, os pesquisadores não sugerem qualquer teoria para explicar a eficácia de seu método.

A necessidade de dispor dos aditivos a nível molecular já praticamente descarta que os mecanismos de grafitização atuantes sejam os de formação-decomposição ou de dissolução-precipitação propostos por Oya e Otani. Seria possível cogitar um mecanismo similar ao de grafitização homogênea desenvolvido pelo boro, mas que agora fosse capaz de se desenvolver a temperaturas reduzidas, além de muito mais eficiente, inclusive para fontes de carbono não grafitizáveis. Por outro lado, a necessidade de moléculas individualizadas desde o início da carbonização e a atuação a baixas temperaturas também levariam à hipótese de que o princípio dessa técnica esteja na capacidade desses agentes grafitizantes de impossibilitar a formação dos anéis de carbono pentagonais e heptagonais que estruturariam 
o carbono não grafitizável. Reduzir a quantidade desses anéis desde o começo da carbonização provavelmente justificaria o estabelecimento de extensas regiões muito bem cristalizadas já a baixas temperaturas. No entanto, ainda não se vê uma explicação para que esses agentes grafitizantes tenham conseguido tornar a grafitização da resina até mesmo mais eficiente que a do piche, visto que o piche ainda teria a vantagem da liberdade de movimento de suas moléculas (o que agilizaria a formação de uma estrutura organizada a longo alcance). Portanto, verifica-se que a técnica desenvolvida por Bartha et al se diferencia das de Oya e Otani por utilizar predominantemente compostos metálicos e organometálicos, e também por exigir o aditivo disponível como molécula. Contudo, além de comprová-la, também ainda é necessário compreender o fenômeno desconhecido que deve existir por trás da técnica de Bartha et al.

\section{CONCLUSÕES}

Pela análise da bibliografia levantada, atestou-se o grande número de caminhos em aberto para explorar as potencialidades das resinas termofixas na produção de carbono, seja para a aplicação em refratários ou mesmo em outras áreas da engenharia de materiais. Como as possíveis alterações a serem testadas envolvem todos os aspectos ligados à resina (ou seja, sua formulação, seu processamento e a pirólise do termofixo), as diversas combinações entre elas praticamente não permitem que se afirme que qualquer uma seja incapaz de levar a resultados interessantes e, assim, que possa ser descartada com antecedência. Porém, ao menos é possível destacar aquelas que se apresentaram como as mais favoráveis para a aplicação específica em refratários contendo carbono. Quanto à formulação, a avaliação de resinas compostas por fenóis substituídos nas posições "meta" ainda se revela muito interessante, visto que aparentam terem sido investigados apenas dois dos diversos compostos fenólicos meta-substituídos possíveis. Além disso, não se verificou qualquer estudo sobre resinas que combinassem esses compostos entre si ou mesmo com o fenol comum. Em relação à proporção formaldeído/ fenol, devido às importantes vantagens apresentadas pelas novolacas, acredita-se que, em um primeiro momento, as razões $\mathrm{F} / \mathrm{P}<1,0$ devam ser sempre preferidas na síntese ou na seleção das resinas fenólicas. A opção pelos resóis ficaria limitada principalmente às situações em que a redução do peso molecular e/ou o acréscimo de solventes não seriam capazes de reduzir a viscosidade das novolacas aos valores desejados, ou quando tais modificações causassem mais prejuízos do que benefícios ao refratário. Quanto aos aditivos antioxidantes, os compostos metálicos convencionais aparentam já ter sido bem explorados pela literatura recente e, portanto, precisariam ser apenas estudados em detalhes para que sejam adequadamente escolhidos. Já quanto aos antioxidantes orgânicos comentados na seção Características da resina para a pirólise, é necessário averiguar se existiriam motivos que impedissem sua aplicação nas resinas destinadas à produção de refratários, pois haveria grande interesse por ganhos na fixação de carbono tão representativos quanto os alcançados na Fig. 13. Na pirólise da resina, comprovando-se a eficácia das alterações da técnica de grafitização catalítica realizadas por Bartha et al [40], seria interessante procurar compreender que mecanismos seriam responsáveis pelo seu êxito para facilitar a continuação de seu desenvolvimento. Um próximo passo para essa técnica que já está sendo cogitado é a anexação do agente catalisador organometálico à estrutura química da resina, o que talvez facilitasse e otimizasse a sua disponibilização a nível molecular, como exigem Bartha et $a l$. Sugere-se que os experimentos que forem planejados para estudar todas essas modificações sejam realizados, sempre que possível, com a própria composição do refratário ou com composições modelos que a simulem, evitando-se assim avaliar amostras de carbono puro. Desse modo, acredita-se que o real impacto dos parâmetros variados sempre será mais realista, visto as incertezas existentes sobre a extensão da influência dos demais constituintes da composição refratária sobre o desenvolvimento da fase carbonácea.

\section{AGRADECIMENTOS}

Os autores agradecem ao CNPq e à Magnesita Refratários SA pelo apoio proporcionado a esta pesquisa.

\section{REFERÊNCIAS}

[1] L. A. Araújo, Manual de Siderurgia volume II, $1^{\circ}$ Ed., Ed. Arte \& Ciência, S. Paulo, Brasil (2005).

[2] E. M. M. Ewais, Carbon based refractories, J. Ceram. Soc. Japan 112, 10 (2004) 512-532.

[3] C. Pascoal, V. C. Pandolfelli, Bauxitas refratárias: composição química, fases e propriedades - Parte I, Cerâmica 46, 298 (2000) 76-82.

[4] M. Hampel, C. G. Aneziris, 49th Int. Coll. Refractories, Ed. Verlag Stahleisen GmbH, Düsseldorf, Alemanha (2006) 21-25.

[5] G. Buchebner, L. Sampayo, V. Samm, 47 ${ }^{\text {th }}$ Int. Coll. Refractories, Aachen, Alemanha (2004) 42-45.

[6] C. G. Aneziris, U. Klippel, $5^{\text {th }}$ Eur. Oxygen Steelmaking Conf., Ed. Verlag Stahleisen GmbH, Aachen, Alemanha (2006) 581-586.

[7] C. G. Aneziris, J. Hubálková, R. Barabás, Microstructure evaluation of $\mathrm{MgO}-\mathrm{C}$ refractories with $\mathrm{TiO}_{2}$ and $\mathrm{Al}$ additions, J. Eur. Ceram. Soc. 27, 1 (2007) 73-78.

[8] B. Rand, B. McEnaney, Carbon binders from polymeric resins and pitch, Part I - Pyrolysis behaviour and structure of the carbons, Brit. Ceram. Trans. J. 84, 5 (1985) 157-165.

[9] P. J. F. Harris, New perspectives on the structure of graphitic carbons, Critical Rev. Solid State Mater. Sci. 30, 4 (2005) 235-253.

[10] H. O. Pierson, "Handbook of carbon, graphite, diamond and fullerenes: properties, processing and applications", Ed. Noyes Publ., Park Ridge, EUA (1993).

[11] G. Zoglmeyr, Technical and environmental aspects of the use of phenolic resins in modern-day refractories, 
Interceram 42, 3 (1993) 145-149.

[12] W. Lian, H. Song, X. Chen, L. Li, J. Huo, M. Zhao, G. Wang, The transformation of acetylene black into onionlike hollow carbon nanoparticles at $1000^{\circ} \mathrm{C}$ using an iron catalyst, Carbon 46, 3 (2008) 525-530.

[13] V. Wiesche, A. Gardziella, R. Solozabal, J. Suren, Unified Int. Technical Conf. Refractories (UNITECR), Ed. Reprints, Aachen, Alemanha (1991) 260-264.

[14] A. Gardziella, J. Suren, M. Belsue, Carbon from phenolic resins: carbon yield and volatile components recent studies, Interceram 41, 7-8 (1992) 461-467.

[15] C. Pagliosa Neto, L. J. Gauckler, "Rheological investigations of phenolic resin interactions with refractory raw materials", Tese Pós-Dr., Swiss Federal Institute of Technology, Zurique, Suíça (2004).

[16] A. Gardziella, L. A. Pilato, A. Knop, "Phenolic Resins: Chemistry, Applications, Standardization, Safety and Ecology", 2a Ed., Ed. Springer, Nova York, EUA (2000). [17] E. V. Krivokorytov, A. G. Gur'ev, B. I. Polyak, Highcarbon binders in refractories and corrosion-resistant ceramics technology (a review), Glass and Ceramics (Steklo i Keramika) 55, 5-6 (1998) 144-147.

[18] M. Chanda, S. K. Roy, "Industrial polymers, specialty polymers, and their applications", 1 1 Ed., Ed. CRC, Boca Raton, EUA (2008)

[19] A. K. Mukhopadhyay, "Industrial Chemical Cresols and Downstream Derivatives", 1 a Ed., Ed. Marcel Dekker, Nova York, EUA (2005).

[20] P. H. R. B. Lemon, Phenol formaldehyde polymers for bonding of refractories, Trans. J. Brit. Ceram. Soc. 84, 2 (1985) 53-56.

[21] E. Yorita, Resin bonded castable refractories, Taikabutsu Overseas 9, 1 (1988) 32-34.

[22] L. Costa, L. Rossi Di Montelera, G. Camino, E. D. Weil, E. M. Pearce, Structure-charring relationship in phenol-formaldehyde type resins, Polymer Degradation and Stability 56, 1 (1997) 23-35.

[23] M. Maciejewski, M. Kedzierski, E. Bednarek, Hyperbranched phenol-formaldehyde resins, Polymer Bull. 38, 6 (1997) 613-620.

[24] Y. H. Kim, Hyperbranched polymers 10 years after, J. Polymer Sci., Part A: Polymer Chem. 36, 11 (1998) 16851698.

[25] T. E. Long, "New family of hyperbranched polymers enhance mechanical, rheological, processing performance", Innovations Report, Março (2004). Disponível em: <http:// www.innovations-report.com $/ \mathrm{html} /$ reports $/$ materials science/report-27581.html>.

[26] T. Ogoshi, T. Saito, T. Yamagishi, Y. Nakamoto, Solubilization of single-walled carbon nanotubes by entanglements between them and hyperbranched phenolic polymer, Carbon 47, 1 (2009) 117-123.

[27] S. Zhang, W. E. Lee, Carbon containing castables:current status and future prospects, Brit. Ceram. Trans. 101, 1 (2002) 1-8.

[28] K. Lenghaus, G. G. H. Qiao, D. H. Solomon, 3,5-Dimethylphenol resole resins: their structure and mechanism of thermal decomposition leading to graphitisation, Polymer 42, 18 (2001) 7523-7529.

[29] R. Imamura, K. Matsui, S. Takeda, J. Ozaki, A. Oya, $A$ new role for phosphorus in graphitization of phenolic resin, Carbon 37, 2 (1999) 261-267.

[30] K. Lenghaus, G. GuangHua Qiao, D. H. Solomon, C. Gomez, F. Rodriguez-Reinoso, A. Sepulveda-Escribano, Controlling carbon microporosity: the structure of carbons obtained from different phenolic resin precursors, Carbon 40, 5 (2002) 743-749.

[31] K. Kobayashi, S. Sugawara, S. Toyoda, H. Honda, An X-ray diffraction study of phenol-formaldehyde resin carbons, Carbon 6, 3 (1968) 359-363.

[32] A. P. Luz, V. C. Pandolfelli, Artigo revisão: atuação dos antioxidantes em refratários contendo carbono, Cerâmica 53, 328 (2007) 334-344.

[33] C. G. Aneziris, U. Klippel, W. Schärfl, V. Stein, Y. Li, Functional refractory material design for advanced thermal shock performance due to titania additions, Int. J. Appl. Ceram. Techn. 4, 6 (2007) 481-489.

[34] Y. W. Li, C. G. Aneziris, X. X. Yi, S. L. Jin, N. Li, Formation of dumbbell-shaped B-SiC whiskers for the manufacturing of advanced composite refractories in the system $\mathrm{Al}_{2} \mathrm{O}_{3}-\mathrm{ZrO}_{2}-\mathrm{C}$, em: "Refractory Manual", Interceram, Editora DVS-Verlag GmbH, Düsseldorf, Alemanha (2005) 20-23.

[35] L. S. Sisinno, A. D. Pereira Netto, E. C. P. Rego, G. S. V. Lima, Hidrocarbonetos policíclicos aromáticos em resíduos sólidos industriais: uma avaliação preliminar do risco potencial de contaminação ambiental e humana em áreas de disposição de resíduos, Cadernos de Saúde Pública 19, 2 (2003) 671-676.

[36] "Amorphous carbon", IUPAC Compendium of Chemical Terminology - the Gold Book, (1995), disponível em <http://goldbook.iupac.org/A00294.html >.

[37] B. McEnaney, B. Rand, Carbon binders from polymeric resins and pitch. Part II - Structure and properties of the carbons, Brit. Ceram. Trans. 84, 6 (1985) 193-198.

[38] P. J. F. Harris, S. C. Tsang, High-resolution electron microscopy studies of non-graphitizing carbons, Phil. Mag. A: Physics of Condensed Matter, Structure, Defects and Mechanical Properties 76, 3 (1997) 667-677.

[39] A. Yamaguchi, S. Zhang, J. Yu, Effect of refractory oxides on the oxidation of graphite and amorphous carbon, J. Am. Ceram. Soc. 79, 9 (1996) 2509-2511.

[40] P. Bartha, H. Jansen, H. G. Daldrup, "Carbonaceous refractory shaped body with improved oxidation behavior and batch composition and method for producing the same", US Patrent 6846766 B1 (2005).

[41] A. Oya, S. Otani, Catalytic graphitization of carbons by various metals, Carbon 17, 2 (1979) 131-137.[32]

[42] A. Oya, H. Marsh, Phenomena of catalytic graphitization, J. Mater. Sci. 17, 2 (1982) 309-322.

[43] A. Oya, R. Yamashita, S. Otani, Catalytic graphitization of carbons by borons, Fuel 58, 7 (1979) 495-500.

[44] S. Zhang, A. Yamaguchi, Effects of $B_{4} C$ on the crystallization and oxidation resistance of carbon from 
resin, J. Ceram. Soc. Japan 102, (1994) 830-834.

[45] A. Oya, M. Mochizuki, S. Otani, I. Tomizuka, An electron microscopic study on the turbostratic carbon formed in phenolic resin carbon by catalytic action of finely dispersed nickel, Carbon 17, 1 (1979) 71-76.

[46] A. Oya, S. Jikihara, S. Otani, Catalytic graphitization of a phenolic resin carbon by nickel $(\sim 100 \mu \mathrm{m})$ : selective gasification of three resultant components as studied by SEM, Fuel 62, 1 (1983) 50-55.

[47] A. Oya, E. Inoue, S. Otani, H. Marsh, Surface areas of turbostratic graphitic carbons prepared from a resin using nickel particles, $20 \mathrm{~nm}$, as graphitization catalyst, Fuel 60, 11 (1981) 1099-1100.

[48] H. Jansen, Bonding of $\mathrm{MgO}-\mathrm{C}$ bricks by catalytically activated resin, Millennium Steel Int. (2007) 95-98.

[49] H. Jansen, C. G. Aneziris, M. Hampel, Y. M. Li, Microstructure and mechanical behaviour of magnesiacarbon bricks bonded by catalytically activated resins, Unified Int. Tech. Conf. Refractories (UNITECR), Dresden, Alemanha (2007) 38-41.

(Rec. 16/05/2010, Rev. 17/09/2010, Ac. 16/10/2010) 